\title{
A Current Review on the Synthesis and Magnetic Properties of M-Type Hexaferrites Material
}

\author{
Virender Pratap Singh ${ }^{1,2^{*}}$, Rohit Jasrotia1, Rajesh Kumar ${ }^{1,2}$, Pankaj Raizada ${ }^{3}$, Sourbh Thakur ${ }^{4}$, \\ Khalid M. Batoo ${ }^{5}$, M. Singh 6
}

${ }^{1}$ School of Physics \& Materials Science, Shoolini University, Bajhol, Solan, India

${ }^{2}$ Himalayan Centre of Excellence in Nanotechnology, Shoolini University, Bajhol, Solan, India

${ }^{3}$ Schoool of Chemistry, Shoolini University, Bajhol, Solan, India

${ }^{4}$ Intitute of Material Science of Kaunas University of Technology, Barsausko, Kaunas, Lithuania

${ }^{5}$ King Abdullah Institute for Nanotechnology, King Saud University, Riyadh, KSA

${ }^{6}$ Department of Physics, Himachal Pradesh University, Shimla, India

Email: *kunwar.virender@gmail.com, rohitsinghjasrotia4444@gmail.com

How to cite this paper: Singh, V.P., Jasrotia, R., Kumar, R., Raizada, P., Thakur, S., Batoo, K.M. and Singh, M. (2018) A Current Review on the Synthesis and Magnetic Properties of M-Type Hexaferrites Material. World Journal of Condensed Matter Physics, 8, 36-61.

https://doi.org/10.4236/wjcmp.2018.82004

Received: January 25, 2018

Accepted: May 25, 2018

Published: May 28, 2018

Copyright $\odot 2018$ by authors and Scientific Research Publishing Inc. This work is licensed under the Creative Commons Attribution-NonCommercial International License (CC BY-NC 4.0). http://creativecommons.org/licenses/by-nc/4.0/ (c) (i) \& Open Access

\begin{abstract}
After the discovery of hexagonal ferrites or hexaferrites, it has been become important materials commercially and technically to study which is still growing on. In this article, we have reviewed about the M-type hexaferrites including their structural, synthesis techniques and important magnetic properties. The role of experimental synthesizing techniques adopted for preparation of M-type hexaferrites on the various parameters studied in this review paper. The substitution of holonium in BaM ferrite reduces the value of coercivity but not saturation magnetization and ramanence and the cobalt-titanium substituted ferrites were the most important M-type ferrites in the field of application in microwave properties and magnetic field industry.
\end{abstract}

\section{Keywords}

Hexagonal Structure, Sol-Gel Synthesis Technique, Co-Precipitation Technique, TEM, VSM

\section{Introduction}

In the recent years, hexagonal ferrites are of great importance to study because of its usage in technological applications such as permanent magnets and also of their excellent magnetic properties and potential applications in various fields 
[1] [2]. Richard Feynman [3] (2005) stated that ferrites are one of the most difficult topics theoretically to study but for the practical applications and studies, it is one of the best topics to come into practice. This will be especially true only when dealing with hexaferrites or hexagonal ferrites (ferrites which have hexagonal crystallographic structure). The world's first permanent magnet came into existence in 1951 which was based on ferroxdure- $\mathrm{BaFe}_{12} \mathrm{O}_{19}$ (also called $\mathrm{BaM})$ [4].

Since after the discovery of hexagonal ferrites in 1950s, the scientist and the technologists showing a lot of interest in studying hexagonal ferrites and it is still going on and in 1955, applications of gyromagnetic properties of hexaferrites started in systematic way [5] [6] [7]. But, nowadays, a lot of theoretical and experimental research work on the various properties and synthesis of hexagonal ferrites have been going on in the laboratory [8]. Recently, there has been much work done in nanotechnology magnetoelectric/multiferroic applications and also in the development of orientation and alignment effects in ferrite fibres [9]. Commercially and technologically, hexagonal ferrites have number of applications in different areas. Also these materials account for the bulk of total magnetic materials which are massively important and are manufactured globally. The different types of hexagonal ferrites are: M-type ferrites such as $\mathrm{BaFe}_{12} \mathrm{O}_{19}$ ( $\mathrm{BaM}$ or barium ferrite), $\mathrm{SrFe}_{12} \mathrm{O}_{19}$ ( $\mathrm{SrM}$ or strontium ferrite), Z-type ferrites $\left(\mathrm{Ba}_{3} \mathrm{Me}_{2} \mathrm{Fe}_{24} \mathrm{O}_{41}\right)$ such as $\mathrm{Ba}_{3} \mathrm{Co}_{2} \mathrm{Fe}_{24} \mathrm{O}_{41}$ or $\mathrm{Co}_{2} \mathrm{Z}$, Y-type ferrites $\left(\mathrm{Ba}_{2} \mathrm{Me}_{2} \mathrm{Fe}_{12} \mathrm{O}_{22}\right)$ such as $\mathrm{Ba}_{2} \mathrm{Co}_{2} \mathrm{Fe}_{12} \mathrm{O}_{22}$ or $\mathrm{Co}_{2} \mathrm{Y}$, W-type ferrites $\left(\mathrm{BaMe}_{2} \mathrm{Fe}_{16} \mathrm{O}_{27}\right)$ such as $\mathrm{BaCo}_{2} \mathrm{Fe}_{16} \mathrm{O}_{27}$ or $\mathrm{Co}_{2} \mathrm{~W}$, X-type ferrites $\left(\mathrm{Ba}_{2} \mathrm{Me}_{2} \mathrm{Fe}_{28} \mathrm{O}_{46}\right)$ such as $\mathrm{Ba}_{2} \mathrm{Co}_{2} \quad \mathrm{Fe}_{28} \mathrm{O}_{46}$ or $\mathrm{Co}_{2} \mathrm{X}$ and U-type ferrites $\left(\mathrm{Ba}_{4} \mathrm{Me}_{2} \mathrm{Fe}_{36} \mathrm{O}_{60}\right)$ such as $\mathrm{Ba}_{4} \mathrm{Co}_{2} \mathrm{Fe}_{36} \mathrm{O}_{60}$ or $\mathrm{Co}_{2}$.

The main purpose of this review is to be focused on the hexagonal ferrites specially, having barium and strontium as divalent cation (BaM or SrM) and their important substituent. The magnetic properties of hexagonal ferrites are linked to their crystal structures intrinsically and they are all ferrimagnetic in nature. However, the magnetic properties of hexagonal ferrites shall be studied practically here and the reasons and the theory behind these magnetic characteristics can be seen in the review by Özgür et al. [9]. This review will totally focus on the synthesis and magnetic properties of hexagonal ferrites especially M-type hexaferrites.

\section{Structure of Hexaferrites}

All the six types of hexagonal ferrites such as $\mathrm{M}, \mathrm{Y}, \mathrm{W}, \mathrm{Z}, \mathrm{X}, \mathrm{U}$ are summarized in Table 1 and the structure of hexagonal can be described by the two approaches such as spinel-based model and block-based model.

\subsection{Spinel-Based Model}

The structure of hexagonal ferrites was same to that of spinel structure which is composed of plates of close packed cubic oxygens with smaller metal ions and 
Table 1. Stiochiometry and basic properties of six types of hexagonal ferrites where * represents $180^{\circ}$ rotation of block around the c-axis [10].

\begin{tabular}{|c|c|c|c|}
\hline Ferrite & Formula & Spinel plates and hexagonal layers & S/R/T structure \\
\hline M & $\mathrm{BaFe}_{12} \mathrm{O}_{19}$ & $2 \mathrm{M}_{5}=\mathrm{B}_{1} \mathrm{~S}_{4} \mathrm{~B}_{1} \mathrm{~S}_{4}$ & $\mathrm{SRS}^{*} \mathrm{R}^{\star}$ \\
\hline $\mathrm{W}$ & $\mathrm{Ba}_{2} \mathrm{Me}_{2} \mathrm{Fe}_{16} \mathrm{O}_{27}$ & $2 \mathrm{~W}_{7}=\mathrm{B}_{1} \mathrm{~S}_{6} \mathrm{~B}_{1} \mathrm{~S}_{6}$ & $\mathrm{SSRS}^{*} \mathrm{~S}^{*} \mathrm{R}^{*}$ \\
\hline $\mathrm{X}$ & $\mathrm{BaMe}_{2} \mathrm{Fe}_{16} \mathrm{O}_{27}$ & $3 \mathrm{X}_{12}=\mathrm{B}_{1} \mathrm{~S}_{4} \mathrm{~B}_{1} \mathrm{~S}_{6} \mathrm{~B}_{1} \mathrm{~S}_{4} \mathrm{~B}_{1} \mathrm{~S}_{6} \mathrm{~B}_{1} \mathrm{~S}_{4} \mathrm{~B}_{1} \mathrm{~S}_{6}$ & $\operatorname{SSRS}^{*} \mathrm{~S}^{*} \mathrm{R}^{*}$ \\
\hline $\mathrm{Y}$ & $\mathrm{Ba}_{3} \mathrm{Me}_{2} \mathrm{Fe}_{14} \mathrm{O}_{41}$ & $2 \mathrm{Y}_{6}=\mathrm{B}_{2} \mathrm{~S}_{4} \mathrm{~B}_{2} \mathrm{~S}_{4} \mathrm{~B}_{2} \mathrm{~S}_{4}$ & $3(\mathrm{ST})$ \\
\hline $\mathrm{Z}$ & $\mathrm{Ba}_{2} \mathrm{Me}_{2} \mathrm{Fe}_{28} \mathrm{O}_{46}$ & $2 \mathrm{Z}_{11}=\mathrm{B}_{2} \mathrm{~S}_{4} \mathrm{~B}_{1} \mathrm{~S}_{4} \mathrm{~B}_{2} \mathrm{~S}_{4} \mathrm{~B}_{1} \mathrm{~S}_{4}$ & $\operatorname{STSRS}^{*} \mathrm{~T}^{\star} \mathrm{S}^{\star} \mathrm{R}^{\star}$ \\
\hline $\mathrm{U}$ & $\mathrm{Ba}_{4} \mathrm{Me}_{2} \mathrm{Fe}_{36} \mathrm{O}_{60}$ & $\mathrm{U}_{16}=\mathrm{B}_{1} \mathrm{~S}_{4} \mathrm{~B}_{2} \mathrm{~S}_{4} \mathrm{~B}_{1} \mathrm{~S}_{4}$ & $\mathrm{SRS}^{*} \mathrm{R}^{\star} \mathrm{S}^{*} \mathrm{~T}^{\star}$ \\
\hline
\end{tabular}

these metal ions are present at octahedral and tetrahedral interstices. The interstices between these layers are filled with three octahedral or one octahedral and two tetrahedral sites and the spinel structure is obtained by the layers of four oxygen atoms repeat three vertical layers to form an $A B C A B C$ lattice. In the hexagonal ferrites, two types of plates $\left(\mathrm{S}_{4}\right.$ and $\left.\mathrm{S}_{6}\right)$ are present which are joined together by two barium containing layers $\left(\mathrm{B}_{1}\right.$ and $\left.\mathrm{B}_{2}\right)$ in which the $\mathrm{M}, \mathrm{Y}$ and $\mathrm{Z}$ consist of only one plate $\left(\mathrm{S}_{4}\right), \mathrm{W}$ structure consist of only one plate $\left(\mathrm{S}_{6}\right)$ and the $\mathrm{X}$ structure consist of two pates $\left(\mathrm{S}_{4}\right.$ and $\left.\mathrm{S}_{6}\right) . \mathrm{B}_{1}$ layer appears in case of $\mathrm{M}, \mathrm{W}, \mathrm{Z}$ ferrites, is a single hexagonal layer which contains the barium atom in position of four oxygen atoms and the $\mathrm{B}_{2}$ layer appears in case of $\mathrm{Z}$ ferrites is two hexagonal layers which contain the two barium atoms in position of eight oxygen atoms. The oxygen atoms remains in $\mathrm{B}_{1}$ layer are arranged in two sets of triangles and the structure of hexagonal ferrite can be studied more deeply by combining the $S$ and $B$ layers which are $S_{2}$-two spinel layers, $M_{5}=a_{1}$-sandwiched between the four spinel layer, $\mathrm{Y}_{6}$-two $\mathrm{B}_{2}$ layers sandwiched between the fourspinel layers as show in Figure 1 [11].

\subsection{S, R and T Blocks}

The $\mathrm{S}$ block has double spinel layer and has the unit formula $\mathrm{Me}_{2} \mathrm{Fe}_{4} \mathrm{O}_{8}$ where $\mathrm{Me}$ is a divalent ion. The $\mathrm{S}$ block composed of two layers of oxygen atoms with three metal atoms. The three metal atoms are present between each layer of four oxygen atoms at four octahedral sites and two tetrahedral sites. At the octahedral sites, the cation is surrounded by six oxygen anions and at the tetrahedral sites, the four oxygen anions surrounded the cation (Figure 2). The $\mathrm{R}$ block has the unit formula $\mathrm{BaFe}_{6} \mathrm{O}_{11}$ and composed of three layers of oxygen atoms where the barium atom takes the position of one of oxygen atom in the centre layer. If the larger barium atom takes the position of the central oxygen atom, then, it creates asymmetry in the cation sites resulted in five octahedral sites, no tetrahedral sites and five coordinate trigonal bipyramidal sites and the $S$ block is seen in the $M$-type ferrites and is the $\mathrm{M}_{5}$ unit in the top and bottom layers removed. The $T$ block has the unit formula $\mathrm{Ba}_{2} \mathrm{Fe}_{8} \mathrm{O}_{14}$ and composed of three layers of oxygen atoms where the barium atom takes the position of one of the oxygen atoms in 


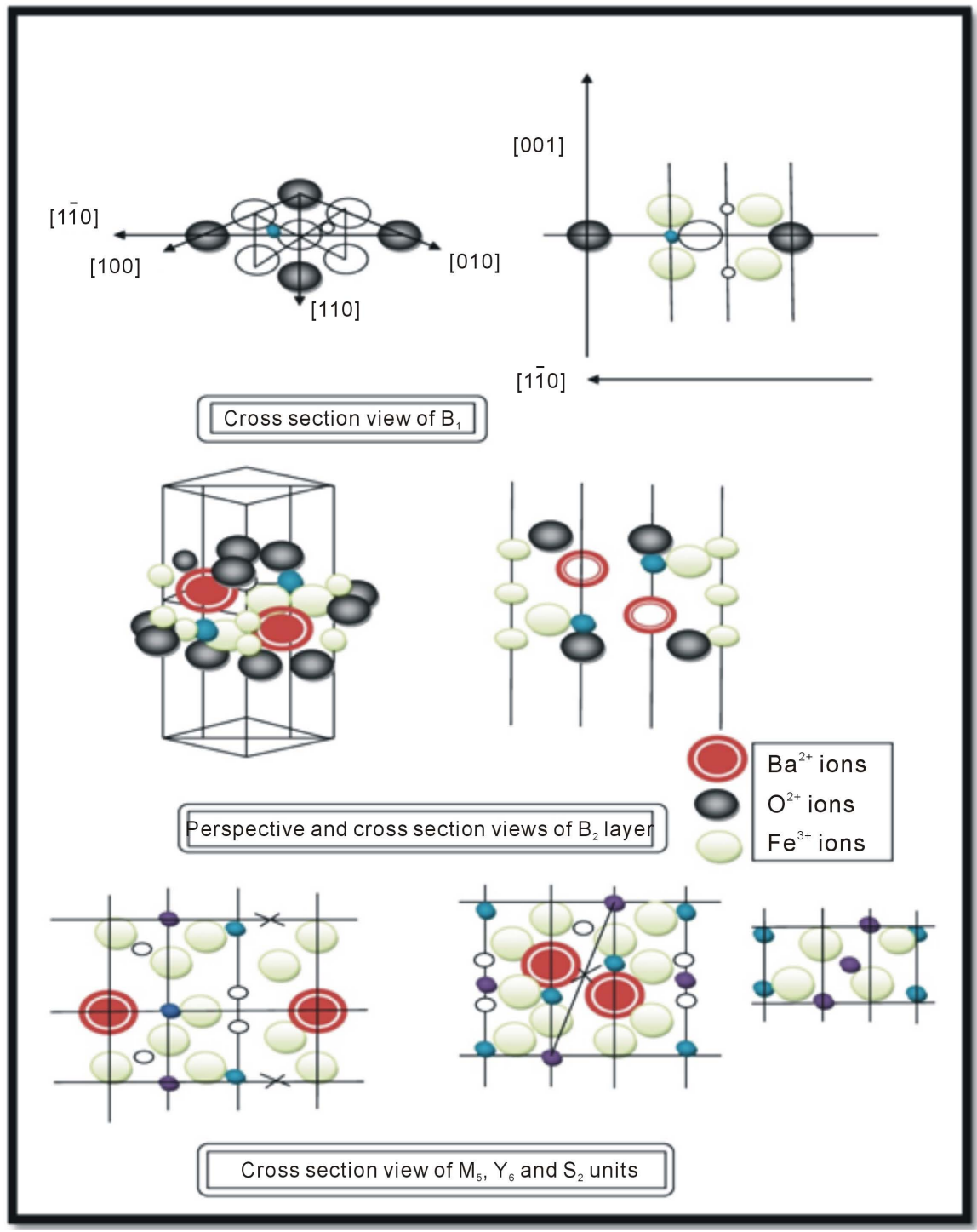

Figure 1. Cross sectional view of $B_{1}$ layer, $B_{2}$ layer and $M_{5}, Y_{6}$ and $S_{2}$ units [11].

the centre two layers. This is the $\mathrm{Y}_{6}$ unit with the top and bottom layers removed [12] [13].

\subsection{Structure of M-Type Ferrites}

The M-ferrite is type of hexagonal ferrite which is composed of one S block and one $\mathrm{R}$ block. These blocks are overlapped with hexagonally and cubic packed layers and also, the plane which contains the barium atom is called mirror plane where the $\mathrm{S}$ and $\mathrm{R}$ blocks are $180^{\circ}$ rotation around the $\mathrm{c}$-axis, so, the mirror block $R, R^{\star}$ providing the unit cell formula SRS ${ }^{\star}{ }^{\star}$ where ${ }^{\star}$ shows the $180^{\circ}$ rotation of the given block around the c-axis. Also, it was demonstrated that the $\mathrm{BaM}$ ferrite composed of stacking of spinel like blocks and substituted M-type ferrite has been investigated on large scale such as $\mathrm{BaFe}_{12-\mathrm{X}} \mathrm{A}_{\mathrm{X}} \mathrm{O}_{19}$. This has been investigated for improving the magnetic properties of $\mathrm{BaM}$ ferrite 


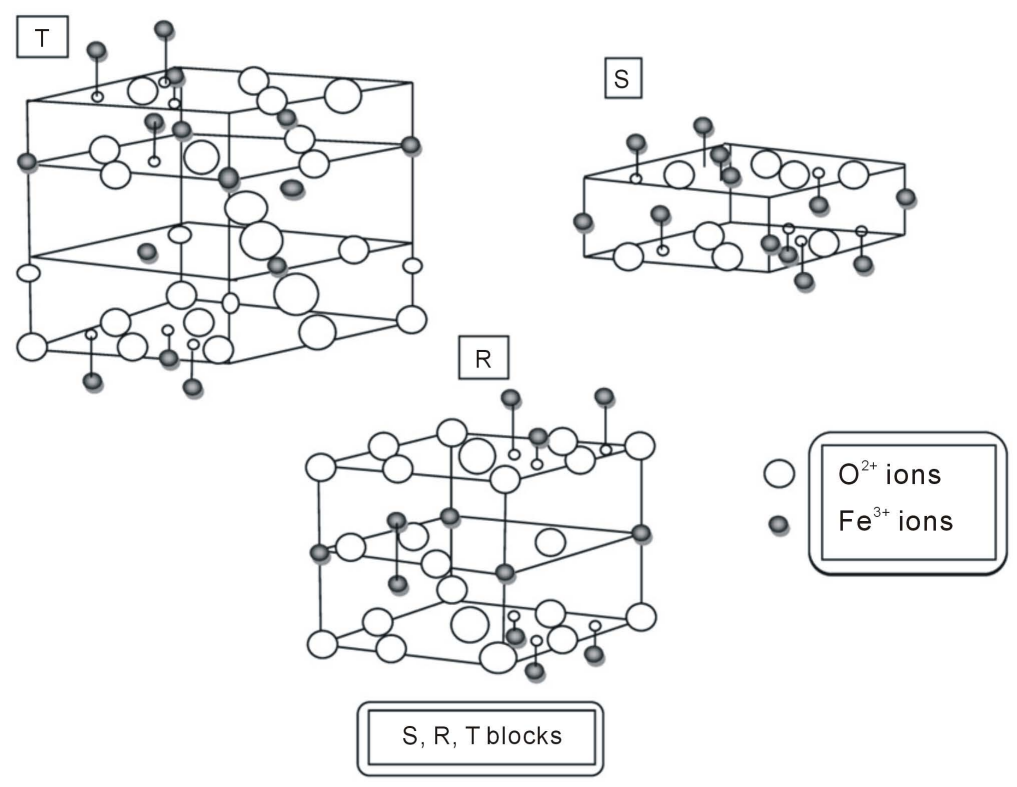

Figure 2. Perspectiveand ball and sticky view of S, R and T blocks [14].

[14] [15] It was also reported that in case of BaM ferrite, the lattice parameters are $\mathrm{c}=23.17 \AA$ and $\mathrm{a}=5.89 \AA$ but in case of SrM ferrite, the lattice parameters are $\mathrm{c}=23.03 \AA$ and $\mathrm{a}=5.86 \AA[16]$ and also, for PbM ferrite, the lattice parameters are $\mathrm{c}=23.02 \AA$ and $\mathrm{a}=5.88 \AA$ [17].Cross section view of the M-type ferrite structure are shown in Figure 3 [18] [19] [20].

\section{Synthesis Techniques for the M-Type Hexaferrites}

A simple method through which the hexagonal ferrites can be produced commercially is standard ceramic method and is ineffective in controlling the grain size and morphology of ferrite powder product. However, there are some other chemical methods through which ferrite precursors powders shall be produced. During synthesizing ferrite powders, we have to take into practice some important factors:

$>$ Heat treatment;

$>$ Chemicals used in starting powders;

$>$ Stoichiometry of powder.

The various methods with the help of which the ferrite precursor powders can be prepared are explained as:

\subsection{Conventional Ceramic Method}

The conventional ceramic method is a simple method which includes mixing and sintering of metal oxides and carbonates precursor powders which should be present in appropriate molar ratios [21] [22] but if the starting sample is mixed at the atomic or ionic level before the reaction occurrence then, the 


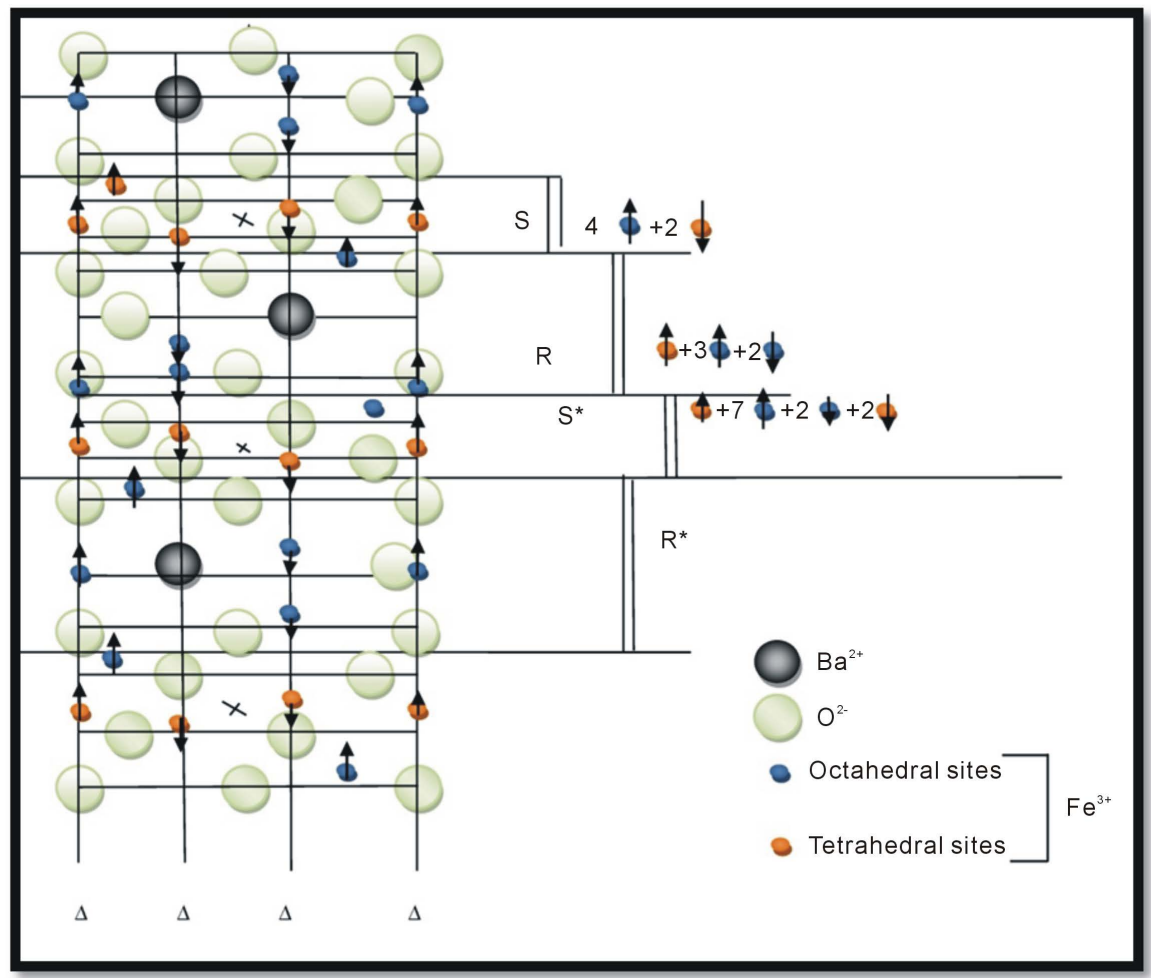

Figure 3. Cross section view of the M-type ferritestructure $\left(\mathrm{BaFe}_{12} \mathrm{O}_{19}\right)$ [18] [19] [20].

crystallization will exists there at lower temperatures and lower sintering temperatures and this can be achieved by ball milling [23]. Ball milling can be done in two ways-dry milling or wet milling. In most of the cases, firstly the powders are mixed which is then milled by balls made of tungsten carbide, stainless steel [24] [25] and then, finally, it is dried and compressed by applying pressure to the responded shapes for full densification and then, at high temperatures, the compacts are sintered. It was found that about approximately $90 \%$ of the theoretical density of $5.28 \mathrm{~g} / \mathrm{cm}^{3}$ for BaM and $5.11 \mathrm{~g} / \mathrm{cm}^{3}$ for SrM. It was demonstrated in a study that pellets of wet milled BaM powder compacted at pressure of approximately $250 \mathrm{MPa}$ and sintered at $1220^{\circ} \mathrm{C}$ for 3 hours were reported to have $90 \%$ of the theoretical density [26], at a pressure approximately $500 \mathrm{MPa}$ and sintered at $1100^{\circ} \mathrm{C}$ for 2 hours were reported to have approximately $80 \%-93 \%$ of the theoretical density [27] and at pressure approximately $30 \mathrm{MPa}$ and sintered at pressure $1150^{\circ} \mathrm{C}$ have less than $70 \%$ of the theoretical density [28].

\subsection{Coprecipitation Method}

The coprecipitation method is used for the synthesis of magnetic nanoparticles. In this method, metal chlorides or nitrates are dissolved in appropriate molar ratios to obtain homogenous solution. Add a base dropwise in the solution for the precipitation of metal powders and then, the co-precipitated powder is washed and dried. This dried powder is, then, sintered at temperature lower than the 
conventional solid state route and the required M-type ferrite were obtained [29] [30] [31]. Several workers are working on the properties and quality of M-type ferrite powders prepared by co-precipitation method and they are doing such investigation on the basis of experimental conditions [32] [33]. In this method, an appropriate amount of $\mathrm{Fe}\left(\mathrm{NO}_{3}\right)_{3} \cdot 9 \mathrm{H}_{2} \mathrm{O}$ was added to NACLO and NACL solutions which are produced through a concentrated solution of $\mathrm{NAOH}$ when chlorine gas was bubbled through a solution of $\mathrm{NAOH}$ and at $\mathrm{Fe}: \mathrm{Ba}=10$ ratio, $\mathrm{BaCl}_{2} \cdot 2 \mathrm{H}_{2} \mathrm{O}$ was added to the $\mathrm{BaM}$ solution. After this, the solution was stand over for one day which is heated for one hour at $80^{\circ} \mathrm{C}$ which was further filtered and rinsed in order to remove the chlorine and alcohol residue and by thisprocess, crystalline barium hydroxide and amphorous ferrihydrite are formed which was structurally related to the $\alpha-\mathrm{Fe}_{2} \mathrm{O}_{3}$ indicates the formation of a pure $\mathrm{BaM}$ phase at a low temperature of $800^{\circ} \mathrm{C}$ [34]. The increase in $\mathrm{PH}$ will result in increase in coercivity which is probably due to the small grain size or particle size and low coercivity is due to the large grain size. With $\mathrm{Fe}: \mathrm{Ba}=10$, the grain size of $\mathrm{BaM}$ hexaferrites decreased with increasing $\mathrm{PH}$ from 11 to 12.5 but the grain size of $\mathrm{BaM}$ was reported to increase with the increasing $\mathrm{PH}$ with $\mathrm{Fe}: \mathrm{Ba}=10.5$ or 11. For $\mathrm{Fe}: \mathrm{Ba}=10$, it was reported that the saturation magnetization is 66.1 $\mathrm{emu} / \mathrm{g}$ at $\mathrm{PH}=11$ which was sintered at $920^{\circ} \mathrm{C}$ is decreased to $43.6 \mathrm{emu} / \mathrm{g}$ at $\mathrm{PH}$ $=12.5$ and the coercivity increases from 3400 Oe to 4334 Oe. For Fe:Ba $=11$, it was reported that the saturation magnetization decreases from $60.1 \mathrm{emu} / \mathrm{g}$ at $\mathrm{PH}$ $=11$ to $46.2 \mathrm{emu} / \mathrm{g}$ at $\mathrm{PH}=12.5$ and the coercivity decreases with the increase in $\mathrm{PH}$ from 4585 Oe to 4435 Oe. Also, with the increase in sintering temperature from $640^{\circ} \mathrm{C}$ to $920^{\circ} \mathrm{C}$, it was observed that the saturation magnetization of co-precipitated powder increases from $25 \mathrm{emu} / \mathrm{g}$ to $65 \mathrm{emu} / \mathrm{g}$ and also, the coercivity increases from 5264 Oe to 5791 Oe which represents single domain particles with typical high coercivity [35] [36]. The steps involved in the preparation of $\mathrm{Al}_{2} \mathrm{O}_{3}-\mathrm{Fe}_{2} \mathrm{O}_{3}$ compounds by coprecipitation technique are given in flow chart shown in Figure 4 [37].

\subsection{Sol-Gel Method}

The sol-gel method is basically used for the manufactured of magnetic powders. In this method, under constant stirring, metal nitrates or metal chlorides water solutions are mixed and if we are working with citrate sol gel method, then, we add to the solution, an appropriate amount of citric acid under constant stirring. After this, a basic solution drop by drop is added to the solution under constant stirring. Due to this, the $\mathrm{PH}$ of the solution is maintained between the range 7 - 9 and the solution is evaporated at $80^{\circ} \mathrm{C}$. After drying and sintering the resulted gel, hexaferrite phase is produced and this is one of the best things that obtained throughout the process. The scientists are working on improving the quality of the products by doing a large numbers of modifications on the method and this is carried out by doing a number of experiments. The SrM ferrites were prepared by sol gel technique after making some modifications in this technique 


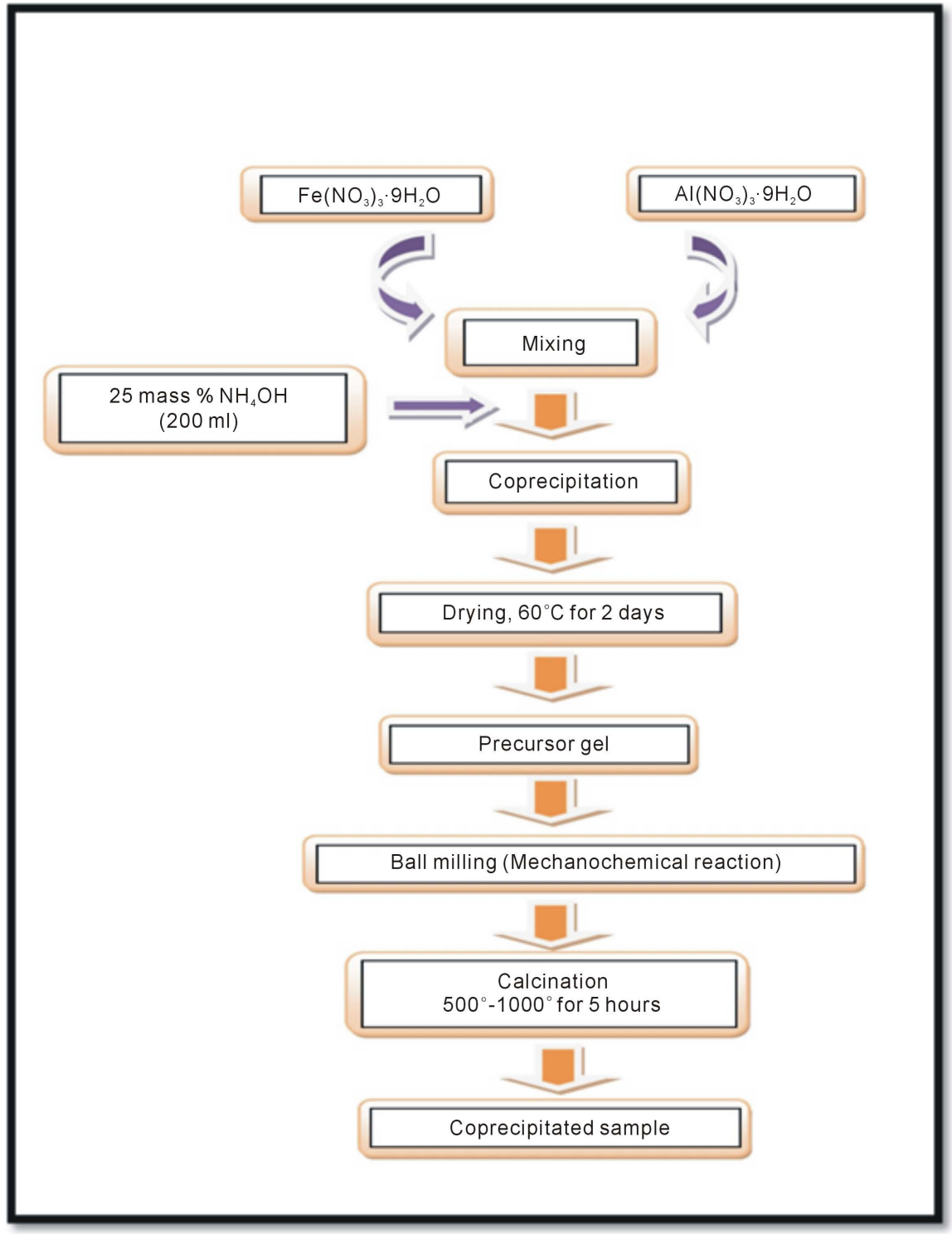

Figure 4. Flow chart of co-precipitation method [37].

which illustrates coercivity of 2213 Oe and a saturation magnetization of 30.61 emu/g but previously we studied [38], with the help of ammonia, $\mathrm{Fe}\left(\mathrm{NO}_{3}\right)_{3}$ water solutions was precipitated and these precipitates were dissolved in citric acid with $\mathrm{BaCO}_{3}$. After that, benzoic acid and ethylene glycol were added to the solution and the given solution was evaporated at $60^{\circ} \mathrm{C}$ and then, the viscous gel produced is dried with the help of heat treatment given at $170^{\circ} \mathrm{C}$ in two ways described below-Route (a) In this route, a heat treatment of $1050^{\circ} \mathrm{C}$ was a heating rate of $4.5^{\circ} \mathrm{C} / \mathrm{min}$ was given to the gel samples placed in the furnace and these samples are heated at different temperatures for different periods of time. Route (b) In this route, the process is slight different. Firstly, the samples are heated at $450^{\circ} \mathrm{C}$ for $5 \mathrm{~h}$ and after this, they have again given a heat treatment in the range $500^{\circ} \mathrm{C}$ to $1250^{\circ} \mathrm{C}$ for $5 \mathrm{~h}$ with a same heating rate of $4.5^{\circ} \mathrm{C} / \mathrm{min}$. The 
various phases were obtained at different temperatures by the samples of route "a" and route "b".

At temperatures $300^{\circ} \mathrm{C}-500^{\circ} \mathrm{C}, \gamma-\mathrm{Fe}_{2} \mathrm{O}_{3}$ and $\mathrm{BaCO}_{3}$ phases was formed by the samples of route a having saturation magnetization of $25-34 \mathrm{emu} / \mathrm{g}$.

At temperatures $\geq 550^{\circ} \mathrm{C}$, BaM phase was formed.

$>$ At temperatures $550^{\circ} \mathrm{C}-900^{\circ} \mathrm{C}, \alpha-\mathrm{Fe}_{2} \mathrm{O}_{3}$ intermediate phase was formed.

$>$ At temperature $650^{\circ} \mathrm{C}-750^{\circ} \mathrm{C}, \mathrm{BaFe}_{2} \mathrm{O}_{4}$ phase was formed and saturation magnetization increased which was reported $44 \mathrm{emu} / \mathrm{g}$ prepared at $650^{\circ} \mathrm{C}$ and the coercivity increased sharply above $650^{\circ} \mathrm{C}$.

> At temperatures $800^{\circ} \mathrm{C}$ to $900^{\circ} \mathrm{C}$, the coercivity comes close to 4200 Oe and the saturation magnetization increase which was reported $65 \mathrm{emu} / \mathrm{g}$ but at temperatures above $900^{\circ} \mathrm{C}$, the coercivity decreases which comes closes to about 3400 Oe. Also, for this temperature, the saturation magnetization reaching about $69 \mathrm{emu} / \mathrm{g}$ by the samples of route $\mathrm{a}$.

On the other hand, a improvement in the magnetic properties were observed by samples of route $\mathrm{b}$ in the temperature ranges specified above but at the temperature range $900^{\circ} \mathrm{C}-950^{\circ} \mathrm{C}$, the samples prepared by route $\mathrm{b}$ was reported to have saturation magnetization and coercivity of $70 \mathrm{emu} / \mathrm{g}$ and 5950 Oe [39]. The steps involved in the sample preparation buy sol-gel technique are given in flow chart shown by Figure 5 [40].

\subsection{Auto-Combustion Method}

The auto-combustion method is known as modified sol-gel citrate method [41] [42] in which the solutions are made from the metal nitrates and citric acid with the appropriate molar solutions present and this solution prepared above is the basic solution made for this technique. After this, a base is drop by drop added to the solution due to which the $\mathrm{PH}$ of the solution reaches in the range $7-8$ [43]. Then, a brown or yellow gel is obtained after heating the solution at $80^{\circ} \mathrm{C}$ which results in the formation of auto-combustion foamy powder by further heating at $220^{\circ} \mathrm{C}-240^{\circ} \mathrm{C}$ [44] [45]. This foamy powder is grinded and sintered at temperatures above $60^{\circ} \mathrm{C}$ which results in the formation of the ferrite powder that is the thing we are looking for and the properties of the these ferrite powder is affected by the $\mathrm{Fe}: \mathrm{Ba}$ ratio calcinated at $900^{\circ} \mathrm{C}$ [45]. The magnetic properties of $\mathrm{BaM}$ was reported to be improved with the increase in Fe:Ba ratio from 1:1 to 1:2 reaching about saturation magnetization, coercivity, ramenance and energy product of $55 \mathrm{emu} / \mathrm{g}, 5000 \mathrm{Oe}, 28 \mathrm{emu} / \mathrm{g}, 1.013 \mathrm{MGOe}$ and also, it was reported that the saturation magnetization of the sample increases with the increase in the calcinated temperature from $700^{\circ} \mathrm{C}$ to $1000^{\circ} \mathrm{C}$ [46]. With Fe:Ba $=11$, it was reported that the samples reaching about the saturation magnetization and coercivity of $51 \mathrm{emu} / \mathrm{g}$ and 4700 Oe but with $\mathrm{Fe}: \mathrm{Ba}=9$, it was reported that the samples reaching about the saturation magnetization and coercivity of $67 \mathrm{emu} / \mathrm{g}$ and 5650 Oe [46]. The steps involved in the sample preparation by auto-combustion technique are given in flow chart shown in Figure 6 [47]. 


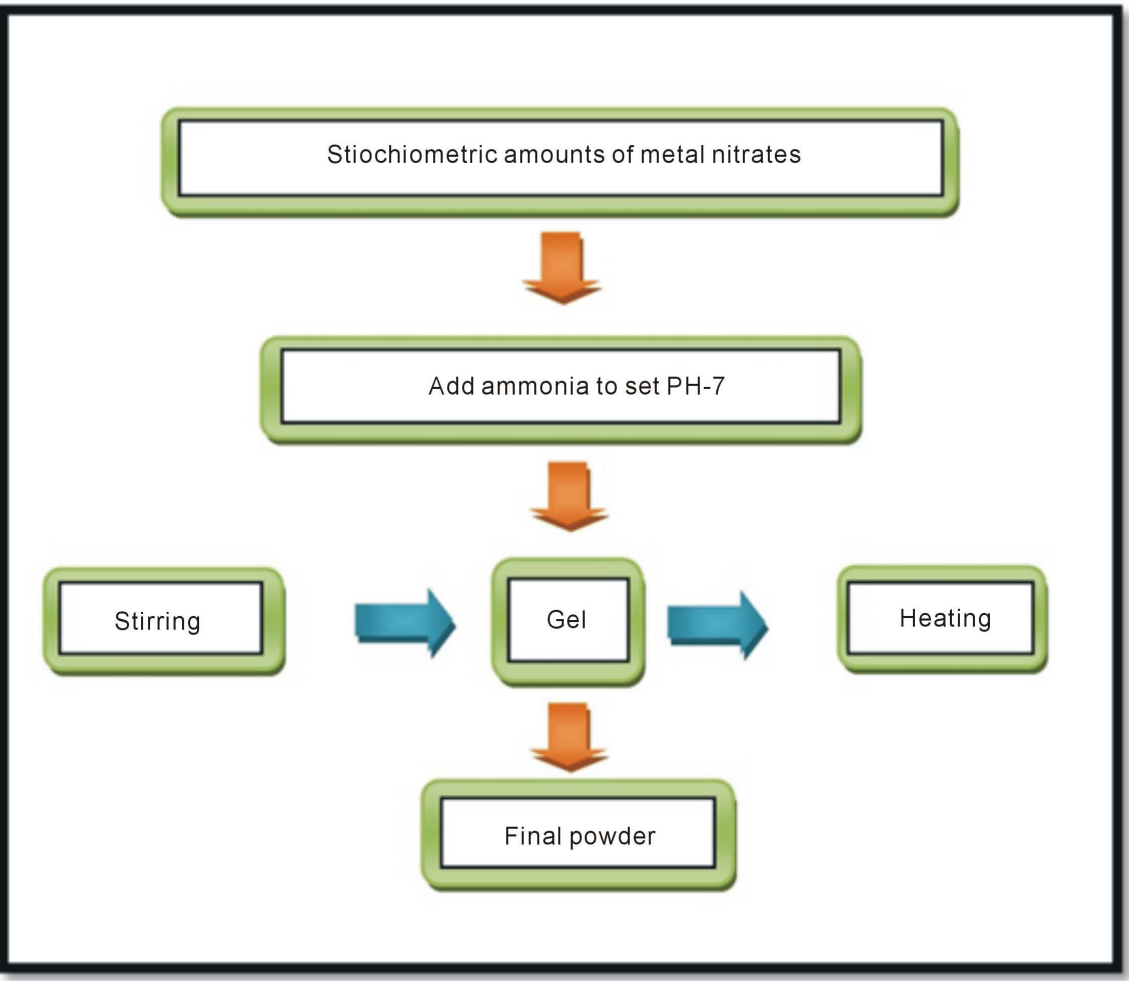

Figure 5. Flow chart of sol-gel technique [40].

\subsection{Hydrothermal Method}

From the last 15 years, the researchers and the scientists showing a great interest in the hydrothermal method and this method is useful in the processing of monostructural, nano-hybrid and nanocomposite materials [48]. In this hydrothermal method, base like $\mathrm{NAOH}$ or $\mathrm{KOH}$ plays an important role with the aid of hydroxide, nitrates and Fe: Ba ratios in the coprecipitation of aqueous solution of metal nitrates and then, the solution is given a heat treatment in the temperature range of $150^{\circ} \mathrm{C}-290^{\circ} \mathrm{C}$ in autoclave. This solution contains the metal precipitates and then, these precipitates were filtered, washed and dried the particles that obtained in an oven after which the dried powder is sintered in the temperature range of $110^{\circ} \mathrm{C}-120^{\circ} \mathrm{C}$. The sintering of dried powders helps us to improve the magnetic characteristics of the resulted product which depends upon the parameters like hydroxide: nitrate ratio, Fe:Ba ratio and the sintering temperature [49]. In the study it was reported that the BaM phase was obtained when there was hydroxide:nitrate ratio $>2$ but the intermediate iron oxide phase was obtained when there was have low hydroxide: nitrate values [49] [50] and the supermagnetic particles obtained when the sample prepared at $150^{\circ} \mathrm{C}$ having hydroxide:nitrate ratios $=16$ [51] [52]. For example with Fe: $\mathrm{Ba}=8$ and hydroxide:nitrate $=2$, as reported that the samples prepared at temperature range of $230^{\circ} \mathrm{C}$ contains the two phases under specific heat treatments. The first phase that was obtained was $\alpha-\mathrm{Fe}_{2} \mathrm{O}_{3}$ under heat treatments of $10 \mathrm{~h}$ and the second phase obtained was $\mathrm{BaM}$ phase under heat treatment of $25 \mathrm{~h}$ and also, under the 

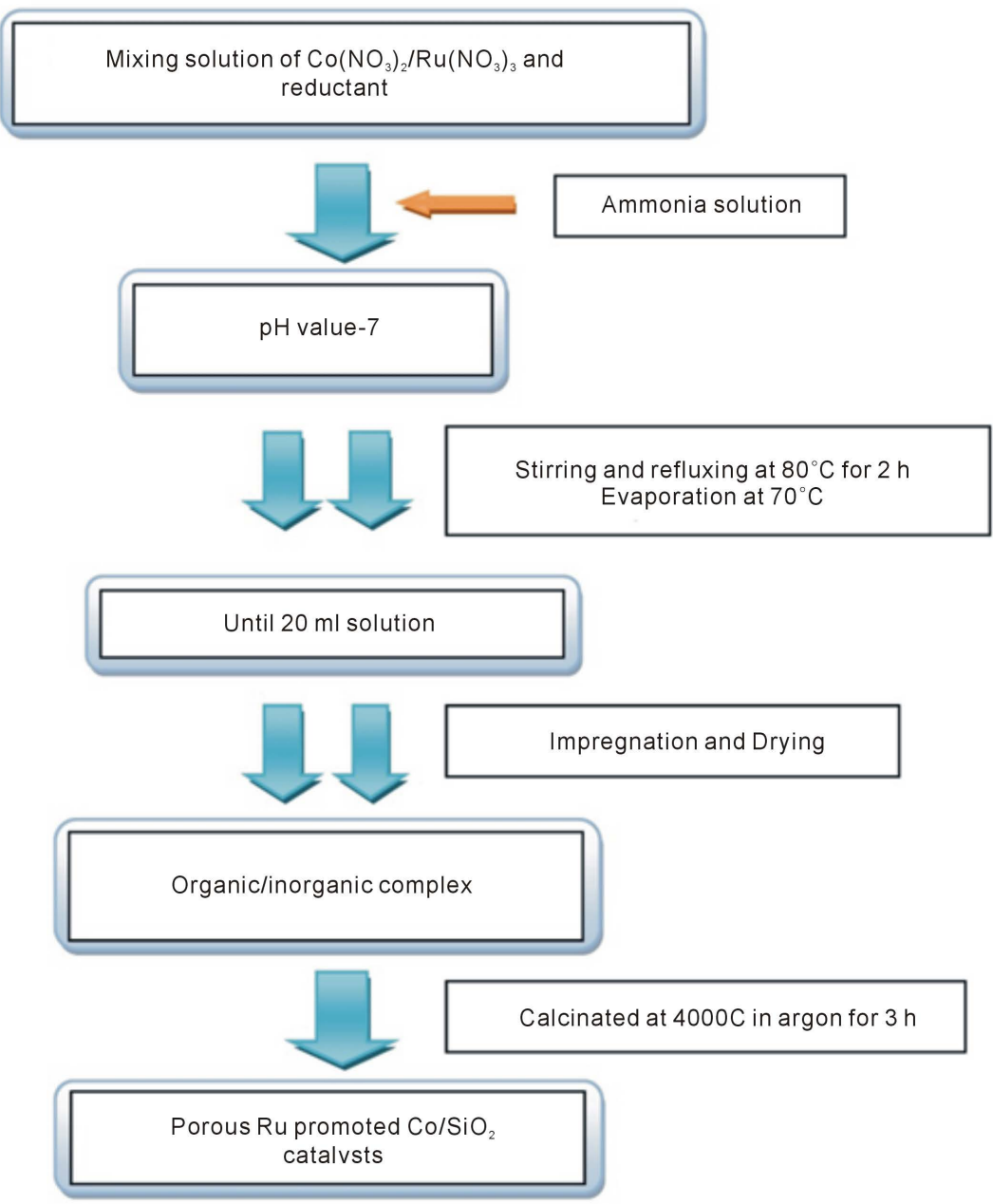

Figure 6. Flow chart for the preparation of catalysts by auto-combustion technique [47].

hydrothermal synthesis, the Fe:Ba ratio is most important in the production of M-type ferrites. The steps involved in the preparation of sample materials are given in flow chart shown in Figure 7 with the help of hydrothermal method [53].

\subsection{Citrate Precursor Method}

The citrate precursor method is a simple synthesis method also known as pecchini method with the aid of which high yield ferrite powders are prepared at temperatures range reaching about $100^{\circ} \mathrm{C}$ [54] [55] and also, it is used for the production of ultrafine particles from the decomposed citrates at low temperatures range [55] [56]. In this method, firstly the appropriate molar ratios of iron and barium nitrates are dissolved in distilled water and then, the solution is mixed with citric acid with a cation:citric acid ratio of 1:1. The ammonia is then, added drop by drop to increase the $\mathrm{PH}$ of the solution forming a homogenous 


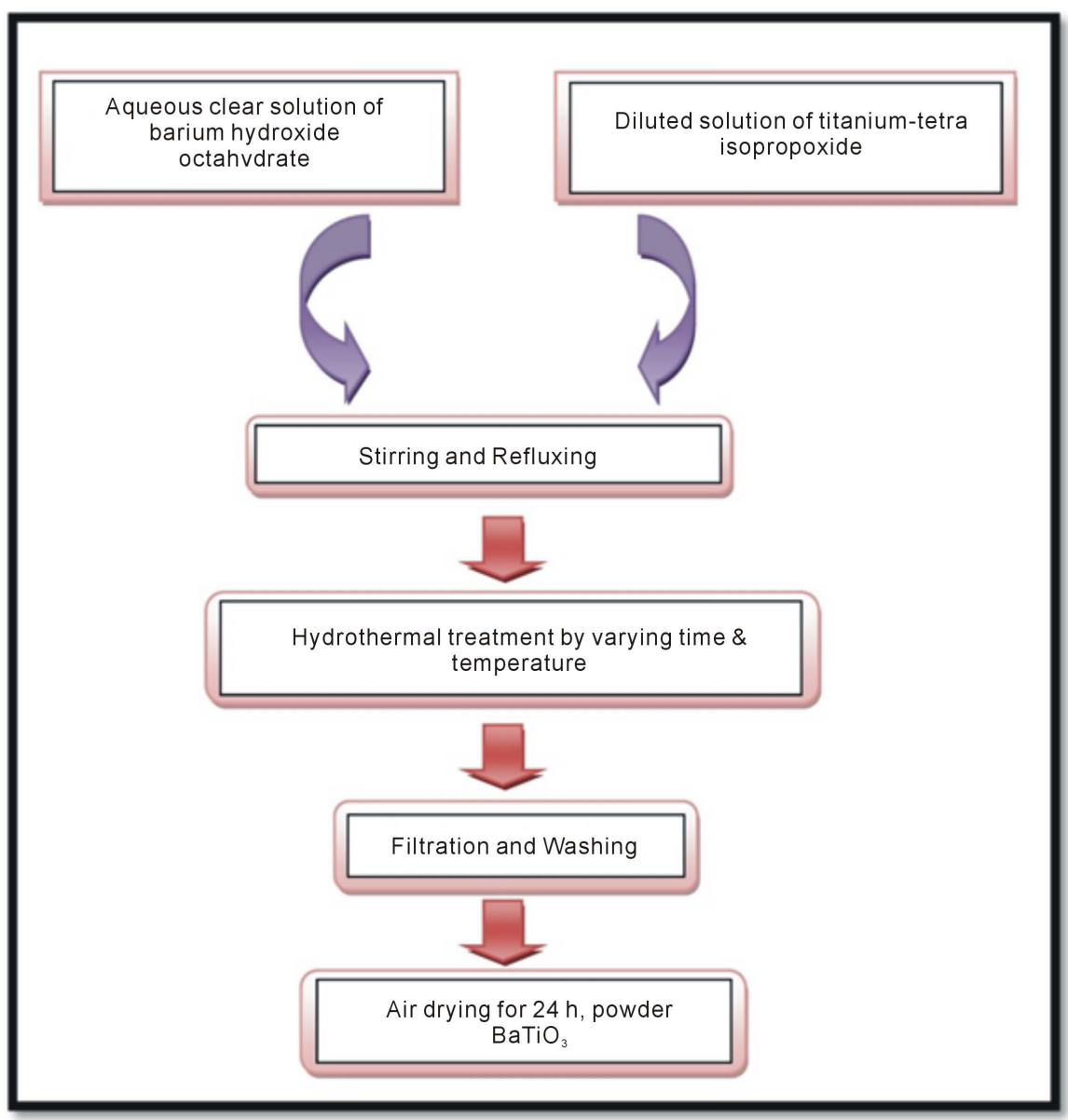

Figure 7. Flow chart of hydrothermal technique [53].

solution which was heated to remove the remaining ammonia in the solution at $80^{\circ} \mathrm{C}$. This solution is added into the ethanol drop by drop, after which the barium iron citrate complex precipitates out by alcohol dehydration and these precipitates are then, dried and heated at $425^{\circ} \mathrm{C}-470^{\circ} \mathrm{C}$ for $48 \mathrm{~h}$. This resulted into $\sim 10 \mathrm{~nm}$ particle and these particles are sintered at specific temperatures to get the BaMpowder. It was reported that the powder sintered at temperature $600^{\circ} \mathrm{C}$ and $700^{\circ} \mathrm{C}$ resulted into $50 \mathrm{~nm}$ and $100 \mathrm{~nm}$ particles. It was found that the 50 $\mathrm{nm}$ particles shows the saturation magnetization of about $33 \mathrm{emu} / \mathrm{g}$ and coercivity about 580 Oe and the $70 \mathrm{~nm}$ particles shows a saturation magnetization of about $35 \mathrm{emu} / \mathrm{g}$ and coercivity of 4800 Oe but the BaM powder sintered at 7000 $C$ resulted into $60 \mathrm{~nm}$ particles which shows a saturation magnetization of 61.5 emu/g prepared by this method [56] [57] [58]. The steps involved in the synthesis of materials by polymeric citrate precursor technique are given in flow chart shown in Figure 8 [59].

\subsection{Molten Salt Method}

The molten salt method is also known as the salt melt method and is one of the best methods for the preparation of ceramic powders. The M-type ferrites can 


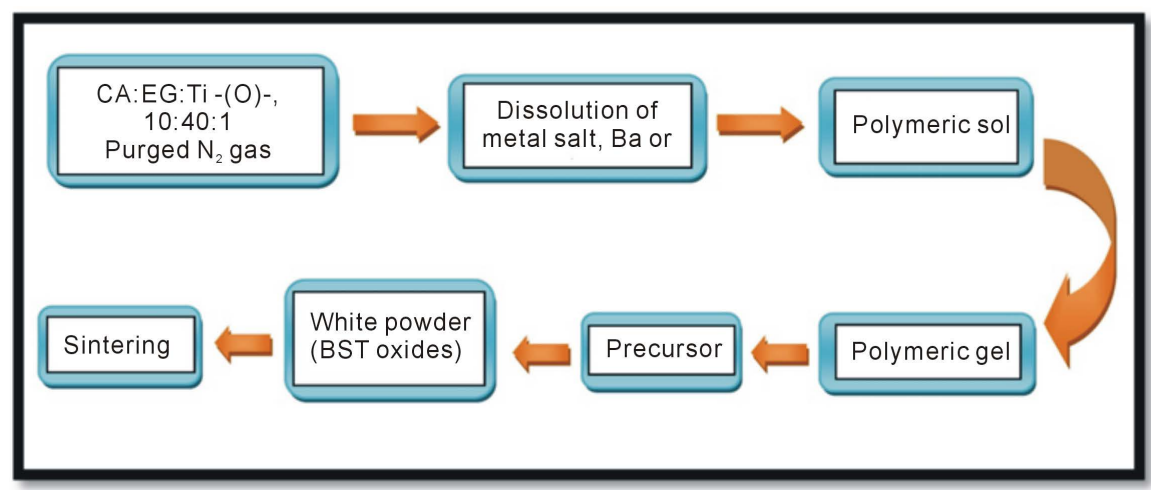

Figure 8. Flow chart of polymeric citrate precursor technique [59].

also be prepared by using this method. The starting solution is prepared by mixing barium carbonate and iron oxide precursor powders to which the potassium chloride and sodium chloride salt mixtures are added to it. Then, heated it at a temperature range of $800^{\circ} \mathrm{C}-1100^{\circ} \mathrm{C}[60]$ and after that, the dried sample is crushed and washed with unionized water to get the salt out of the dry sample to get the magnetic powder. It has been demonstrated that the magnetic properties of $\mathrm{BaM}$ depends on the optimal experimental conditions such as saturation magnetization, coercivity etc. and the BaM with the good magnetic properties (saturation magnetization of $72 \mathrm{emu} / \mathrm{g}$ and coercivity of $4300 \mathrm{Oe}$ ) can be made with an appropriate molar ratio of $\mathrm{Fe}: \mathrm{Ba}=10$ with the aid of molten salt method [60] [61]. The preparation procedure for the sample material is given in flow chart shown in Figure 9 [62].

\section{Further Developments in the Synthesis Techniques of M-Type Hexaferrites}

It has been demonstrated that the $\mathrm{BaM}$ hexaferrites powders composed of three phases which are $\mathrm{BaM}$, intermediate $\mathrm{BaFe}_{2} \mathrm{O}_{4}$ and $\mathrm{Fe}_{2} \mathrm{O}_{3}$ and these powders are prepared by conventional ceramic technique [63] which is the simple technique in controlling the grain size and morphology of ferrite powder product but addition of $\mathrm{B}_{2} \mathrm{O}_{3}$ in small appropriate amounts to the $\mathrm{BaM}$ powder results in $\mathrm{BaM}$ phase only with the enhanced remanent magnetization. It was observed that the addition of $\mathrm{B}_{2} \mathrm{O}_{3}$ in the $\mathrm{BaM}$ powder prepared helps in improving the magnetic characteristics of $\mathrm{BaM}$ hexaferrite. It has also been improved by doing etching with $\mathrm{HCL}$ solution along with $\mathrm{B}_{2} \mathrm{O}_{3}$ addition [64]. It was reported that addition of $1 \%$ of $\mathrm{B}_{2} \mathrm{O}_{3}$ to the $\mathrm{BaM}$ powder results in saturation magnetization of $54 \mathrm{emu} / \mathrm{g}$, remanence magnetization of $28 \mathrm{emu} / \mathrm{g}$ and coercivity of 2000 to 3000 Oe but the addition of $0.1 \%$ of $\mathrm{B}_{2} \mathrm{O}_{3}$ to the $\mathrm{BaM}$ powder results in the saturation magnetization of $63.3 \mathrm{emu} / \mathrm{g}$ and ramenance magnetization of $34.9 \mathrm{emu} / \mathrm{g}$ [64].The BaM hexaferrite obtained powders with low coercivity prepared by oxalate precursor technique [65] but it has been reported that the coercivity and the saturation magnetization increases with the increase of temperature from $900^{\circ} \mathrm{C}$ to $1100^{\circ} \mathrm{C}$ when we prepared the powders by taking the starting solutions prepared by 


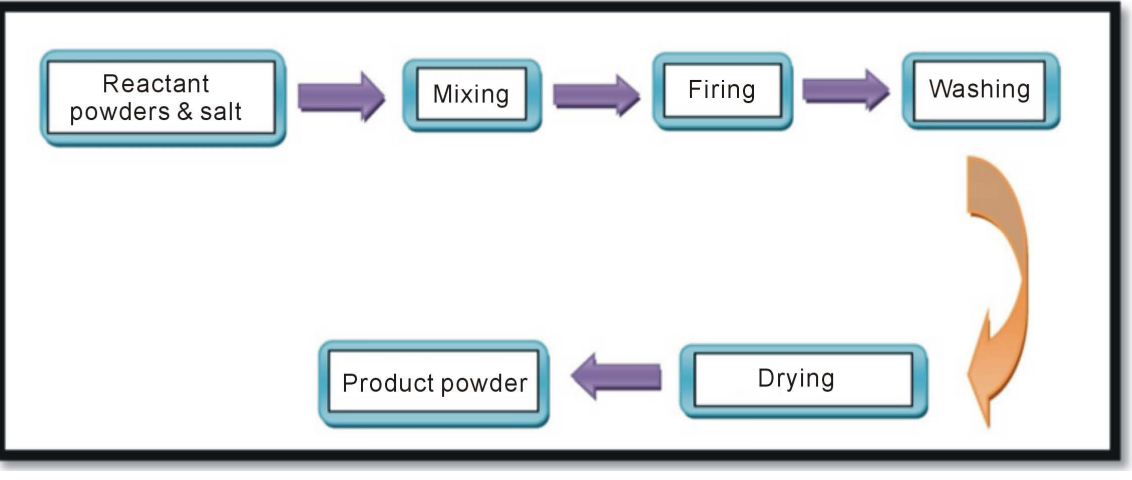

Figure 9. Flow chart of molten salt synthesis of ceramic powders [62].

dissolving the metal chlorides in equal amounts of oxalic acid with a ratio of $\mathrm{Fe}: \mathrm{Ba}=12$ and clean the solution with constant stirring on stirrer about $15 \mathrm{mi}-$ nutes which was then, heated at $80^{\circ} \mathrm{C}$ on magnetic stirrer with hot plate and dried it at $100^{\circ} \mathrm{C}$ on stirrer with hot plate for 12 hours and then, finally calcinated it for 2 hours in the temperature range of $800^{\circ} \mathrm{C}-1200^{\circ} \mathrm{C}$. It was reported that the powder prepared exhibit saturation magnetization at a maximum value was about $66.36 \mathrm{emu} / \mathrm{g}$ and the coercivity at a maximum value was about 640 Oe. It was also demonstrated a new technique has been developed for preparing the high quality hexaferrites at low Fe:Ba ratios [66] called ammonium nitrate melt synthesis [67]. The starting solution is prepared by mixing the appropriate quantities of $\mathrm{BaCO}_{3}$ and $\mathrm{Fe}_{2} \mathrm{O}_{3}$ in the ammonium nitrate melt. Stir it on magnetic stirrer with hot plate and then, heat it at $260^{\circ} \mathrm{C}$. This results in reddish precipitates which were further heated for 5 hours at $450^{\circ} \mathrm{C}$ and the parts of the powder obtained was provided a heat treatment at $800^{\circ} \mathrm{C}-1200^{\circ} \mathrm{C}$ for observing the optimal heat treatment. It was reported that the powder sintered at $1100^{\circ} \mathrm{C}$ gives two phases $\mathrm{BaFe}_{2} \mathrm{O}_{4}$ and $\mathrm{BaM}$ but powder washed with HCL solution gives $\mathrm{BaM}$ phase only. This only one BaM phase observed with a saturation magnetization of about $66.7 \mathrm{emu} / \mathrm{g}$, coercivity of 4228 Oe and remanent magnetization of about $38.5 \mathrm{emu} / \mathrm{g}$. It has observed that hexaferrite powders prepared by the synthesis techniques described above directly affects the quality and magnetic characteristics of powders prepared and also, the hexaferrites having low values of coercivity and saturation magnetization are useful in the field of magnetic recording applications but the hexaferrites having high values of coercivity and saturation magnetization are useful in the field of permanent magnets (PM). In Table 2, some of the values are listed on the basis of experimental findings that deal with the magnetic properties of the hexagonal ferrites in the field of permanent magnets and the magnetic recording applications.

\section{Magnetic Properties of M-Type Hexaferrites}

M-type barium hexaferrite also called as the BaM hexaferrite is the most important M-type hexaferrite in the field of magnetic recording industry and microwave properties and it is ferrimagnetic in nature with a maximum density of $\rho=$ 
$5.25 \mathrm{~g} / \mathrm{cm}^{3}$ and coercivity of $160-255 \mathrm{~K} \cdot \mathrm{Am}^{-1}$. Table 3 shows the magnetic properties or characteristics of $\mathrm{M}$-type hexaferrite where $\mathrm{M}_{\mathrm{s}}$ represents saturation magnetization, $\mathrm{H}_{\mathrm{c}}$ represents coercivity and $\mathrm{k}_{1}$ represents first order anisotropy constant [79].

\subsection{Ba-M Ferrite}

It has been demonstrated that the various observations have be made on the single domain size of BaM ferrite, initially its value was found to be as 1.3 um but after performing the experiments, its value found as being 1.8um [79]. If its value will be observed by using Kettle's theory, then, it is found as being $0.3-0.9$ um [80] and also, the domain size increases with the increase in temperature. The BaM ferrite have high theoretical value of coercivity reported around 594 $\mathrm{K} \cdot \mathrm{Am}^{-1}$ and also have high value of saturation magnetization reported around 72 $\mathrm{Am}^{2} \cdot \mathrm{Kg}^{-1}$ but the BaM ferrite prepared by using conventional ceramic technique have low value of coercivity reported around $159-255 \mathrm{~K} \cdot \mathrm{Am}^{-1}$ and have high

Table 2. Magnetic properties of M-type hexaferrites obtained through the various experimental synthesis techniques [68].

\begin{tabular}{|c|c|c|c|c|c|}
\hline $\begin{array}{l}\text { Synthesis } \\
\text { Technique }\end{array}$ & $\begin{array}{c}\mathrm{M}_{\mathrm{s}} \\
(\mathrm{emu} / \mathrm{g})\end{array}$ & $\begin{array}{c}\mathrm{M}_{\mathrm{r}} \\
(\mathrm{emu} / \mathrm{g})\end{array}$ & $\begin{array}{c}\mathrm{H}_{\mathrm{C}} \\
(\mathrm{emu} / \mathrm{g})\end{array}$ & Applications & Reference \\
\hline \multirow{3}{*}{$\begin{array}{c}\text { Conventional } \\
\text { ceramic } \\
\text { technique }\end{array}$} & 61 & 32 & 2080 & HPMR & {$[68]$} \\
\hline & 49 & 24 & 1050 & HLMR & [69] \\
\hline & 71 & 37 & 4020 & PM & {$[70]$} \\
\hline \multirow{3}{*}{$\begin{array}{c}\text { Coprecipitation } \\
\text { technique }\end{array}$} & 64 & 31 & 4700 & $\mathrm{PM}$ & [71] \\
\hline & 69 & 36 & 5440 & $\mathrm{PM}$ & {$[75]$} \\
\hline & 60 & 15 & 860 & HLMR & {$[72]$} \\
\hline \multirow{3}{*}{$\begin{array}{l}\text { Sol-gel } \\
\text { technique }\end{array}$} & 61 & 37 & 4996 & $\mathrm{PM}$ & {$[73]$} \\
\hline & 59 & 36 & 1920 & HPMR & {$[74]$} \\
\hline & 61 & 36 & 5692 & PM & {$[75]$} \\
\hline \multirow{3}{*}{$\begin{array}{l}\text { Molten Salt } \\
\text { technique }\end{array}$} & 59 & - & 4820 & $\mathrm{PM}$ & {$[76]$} \\
\hline & 72 & - & 4650 & $\mathrm{PM}$ & {$[77]$} \\
\hline & 72 & - & 4300 & $\mathrm{PM}$ & [77] \\
\hline \multirow{3}{*}{$\begin{array}{l}\text { Hydrothermal } \\
\text { technique }\end{array}$} & 40 & - & 2500 & PM, HPMR & [77] \\
\hline & 59 & 20 & 1350 & HPMR & {$[78]$} \\
\hline & 60 & - & 2300 & PM, HPMR & [78] \\
\hline
\end{tabular}

Table 3. Magnetic properties of BaM and SrM hexaferrites [79].

\begin{tabular}{cccccccc}
\hline $\begin{array}{c}\text { M-type } \\
\text { Ferrite }\end{array}$ & $\begin{array}{c}\text { Chemical } \\
\text { formula }\end{array}$ & $\mathbf{M}_{\mathrm{S}}$ & $\begin{array}{c}\text { Coercivity } \\
\left(\mathrm{H}_{\mathrm{C}}\right)\end{array}$ & $\begin{array}{c}\text { Isotropic } \\
\mathbf{M}_{\mathbf{r}} / \mathbf{M}_{\mathbf{s}}\end{array}$ & $\begin{array}{c}\mathrm{H}_{\mathrm{A}} \\
\left(\mathrm{K} \cdot \mathrm{Am}^{-1}\right)\end{array}$ & $\begin{array}{c}\mathrm{K}_{1} \\
\left(10^{5} \mathbf{j m}^{-3}\right)\end{array}$ & $\begin{array}{c}\mathrm{T}_{\mathrm{C}} \\
\left({ }^{\circ} \mathrm{C}\right)\end{array}$ \\
\hline $\mathrm{SrM}$ & $\mathrm{SrFe}_{12} \mathrm{O}_{19}$ & $92-74$ & High value & 0.50 & 1592 & 3.5 & 460 \\
$\mathrm{BaM}$ & $\mathrm{BaFe}_{12} \mathrm{O}_{19}$ & 72 & High value & 0.50 & 1353 & 3.3 & 450 \\
\hline
\end{tabular}


value of saturation magnetization reported around $70 \mathrm{Am}^{2} \mathrm{Kg}^{-1}$ [80]. However, it has been observed that with the increase in temperature, the coercivity also increases. Example from $135 \mathrm{~K} \cdot \mathrm{Am}^{-1}$ at $-200^{\circ} \mathrm{C}$ to $255 \mathrm{~K} \cdot \mathrm{Am}^{-1}$ at $25^{\circ} \mathrm{C}$ and peak at $380 \mathrm{~K} \cdot \mathrm{Am}^{-1}$ at $250^{\circ} \mathrm{C}$. After this specified point, the coercivity decreases [81]. $\mathrm{BaM}$ ferrite prepared with the help of organic precursor synthesis gives high value of saturation magnetization reported around $70 \mathrm{Am}^{2} \cdot \mathrm{Kg}^{-1}$ and low value of coercivity reported around $240 \mathrm{~K} \cdot \mathrm{Am}^{-1}$ at a temperature of $900^{\circ} \mathrm{C}$ for one hour with the grain size of $200 \mathrm{~nm}$ but BaM ferrite prepared with the help of non-stoichiometric aqueous sol-gel synthesis gives high value of coercivity reported around $470 \mathrm{~K} \cdot \mathrm{Am}^{-1}$ and low value of saturation magnetization reported around $55.7 \mathrm{Am}^{2} \cdot \mathrm{Kg}^{-1}$ with the same temperature and same grain size as in case of organic sol-precursor synthesis. Table 4 shows the characteristics of BaM ferrite where $\rho$ represents X-ray density, $\mu_{\mathrm{B}}$ represents the number of Bohr magnetrons, molecular mass, measured $M_{s}$ at room temperature, calculated $M_{s}$ at zero Kelvin and $\mathrm{T}_{c}$ in case of BaM ferrite [81].

\subsection{Substituted BaM Ferrrite}

It has been observed the substitution was done in a ferrite for increasing its purity or we can say that for increasing the value of saturation magnetization. M-type barium hexaferrite also called as BaM is the most important M-type hexaferrite and in this case, substitution of non-magnetic ions such as zinc ions $\left(\mathrm{Zn}^{2+}\right)$ has been made for increasing the value of saturation magnetization and also, the zinc ions most probable occupy the tetrahedral sites which oppose the octahedral sites in the M-type ferrites to obtain the magnetic moment. Thus, the zinc ions increase the net magnetic moment by reducing the negative participation and zinc substituted $\mathrm{BaM}$ ferrite have high value of saturation magnetization reported around $65 \mathrm{Am}^{2} \cdot \mathrm{Kg}^{-1}$ and coercivity around $199 \mathrm{~K} \cdot \mathrm{Am}^{-1}$. BaM doped with antimony for $\mathrm{x}$ goes to 1 by hydrothermal technique gives low value of coercivity reported around $36 \mathrm{KAm}^{-1}$ and also, low value of saturation Magnetization. The low value of saturation magnetization is due to the presence of $\mathrm{Sb}_{2} \mathrm{O}_{3}$ produc. But, the $\mathrm{BaM}$ prepared by sol-gel technique doped with arsenic and antimony reduces the values of magnetic characteristics such as saturation magnetization, coercivity etc. [82]. The different values of saturation magnetization and coercivity are calculated by using the different synthesis techniques at the various specified temperatures for the BaM ferrite and substituted BaM ferrite are shown in Table 5 [82].

\subsection{Holonium Substituted BaM Ferrites}

The effect of substitution of Holonium on the structural and magnetic properties of BaM ferrite was studied by using various techniques like XRD (X-ray diffraction), TEM (Transmission electron microscopy), Hysteresis loop etc.

\subsubsection{Experimental Process}

The starting powders were prepared by using combined method of sol-gel and 
Table 4. Characteristics of BaM ferrite [81].

\begin{tabular}{ccccccc}
\hline M-type ferrite & $\begin{array}{c}\rho \\
\left(\mathrm{g} / \mathrm{cm}^{3}\right)\end{array}$ & $\mu_{\mathrm{B}}$ & $\begin{array}{c}\text { Molecular } \\
\text { mass }(\mathrm{g})\end{array}$ & $\begin{array}{c}\text { Measured } \mathrm{M}_{\mathrm{s}} \\
\text { at room temp. } \\
\left(\mathrm{Am}^{2} \cdot \mathrm{Kg}^{-1}\right)\end{array}$ & $\begin{array}{c}\text { Calculated } \\
\mathrm{M}_{\mathrm{S}} \text { at } 0 \mathrm{~K} \\
\left(\mathrm{Am}^{2} \cdot \mathrm{Kg}^{-1}\right)\end{array}$ & $\mathrm{T}_{\mathrm{c}}\left({ }^{\bullet} \mathrm{C}\right)$ \\
\hline $\mathrm{BaM}$ & 5.28 & 20 & 1112 & 72 & $>100$ & 450 \\
\hline
\end{tabular}

Table 5. RT saturation magnetization and coercivity values for BaM and substituted BaM ferrite [82].

\begin{tabular}{cccc}
\hline $\begin{array}{c}\text { M-type } \\
\text { ferrite }\end{array}$ & Synthesis technique/composition & $\begin{array}{c}\mathbf{M}_{\mathbf{s}} \\
\left(\mathbf{A m}^{2} \cdot \mathbf{K g}^{-1}\right)\end{array}$ & $\begin{array}{c}\mathbf{H}_{\mathbf{c}} \\
\left(\mathbf{K} \cdot \mathbf{A m}^{-1}\right)\end{array}$ \\
\hline \multirow{3}{*}{$\mathrm{BaM}$} & Sol-gel unprefired, $1050^{\circ} \mathrm{C}$ & 70 & 286 \\
& Sol-gel prefired, $900^{\circ} \mathrm{C}$ & 70 & 474 \\
& Sol-gel derived fibers, $100^{\circ} \mathrm{C}$ & $58.4-63.8$ & $401-428$ \\
Substituted & & 65 & 199 \\
BaM & $\mathrm{Zn} \mathrm{substituted} \mathrm{BaM}$ & 79 & 0.40 \\
\hline
\end{tabular}

auto-combustion process for $\mathrm{x}$ goes from 0.01 to $0.04(0.01,0.02,0.03,0.04)$. The various techniques have been used for determine the crystal structure, particle sizeand morphology, magnetic behavior which are XRD, SEM and VSM. The magnetic measurements, magnetic behavior and magnetic properties of the prepared samples were examined by using VSM (vibrating sample magnetometer). The particle size and morphology of the prepared samples were examined by using SEM (scanning electron microscopy) but the structure, composition and properties of the prepared samples were examined by using TEM ( transmission electron microscopy).

\subsubsection{XRD Analysis}

The XRD patterns of Holonium substituted BaM hexaferrites for variation of $\mathrm{x}=$ 0.1, 0.2, 0.3, 0.4 given in Figure 10 which shows that with the increase in doping of $\mathrm{Ho}^{3+}$ ions, secondary phase of $\mathrm{Fe}_{2} \mathrm{O}_{3}$ was seen which was also observed by various other researchers [83] [84] [85]. With the help of Scherer's formula, the particle size " $t$ " was obtained for (114) \& (107) peaks and with the increase in the doping of $\mathrm{Ho}^{3+}$ ions, the particle size also decreases from $51 \mathrm{~nm}$ to $44 \mathrm{~nm}$ [86] [87] [88] and also, due to the difference in the ionic radii of $\mathrm{Ho}^{3+}$ (1.04 $\AA$ ) [89] and $\mathrm{Fe}^{3+}(0.67 \AA)$ [90], extra phase exists.

\subsubsection{TEM Analysis}

The particle size and microstructural morphology of prepared samples of Holonium substituted barium nanohexaferrites was confirmed by studying its TEM, SAED and HRTEM patterns given in Figure 11 which shows that the average size increases from $45 \mathrm{~nm}$ to $60 \mathrm{~nm}$.

\subsubsection{Magnetism}

For ferrite based nanostructure materials all the magnetic parameters can be calculated from the M-H Study. Figure 12 shows the hysteresis loop determined 


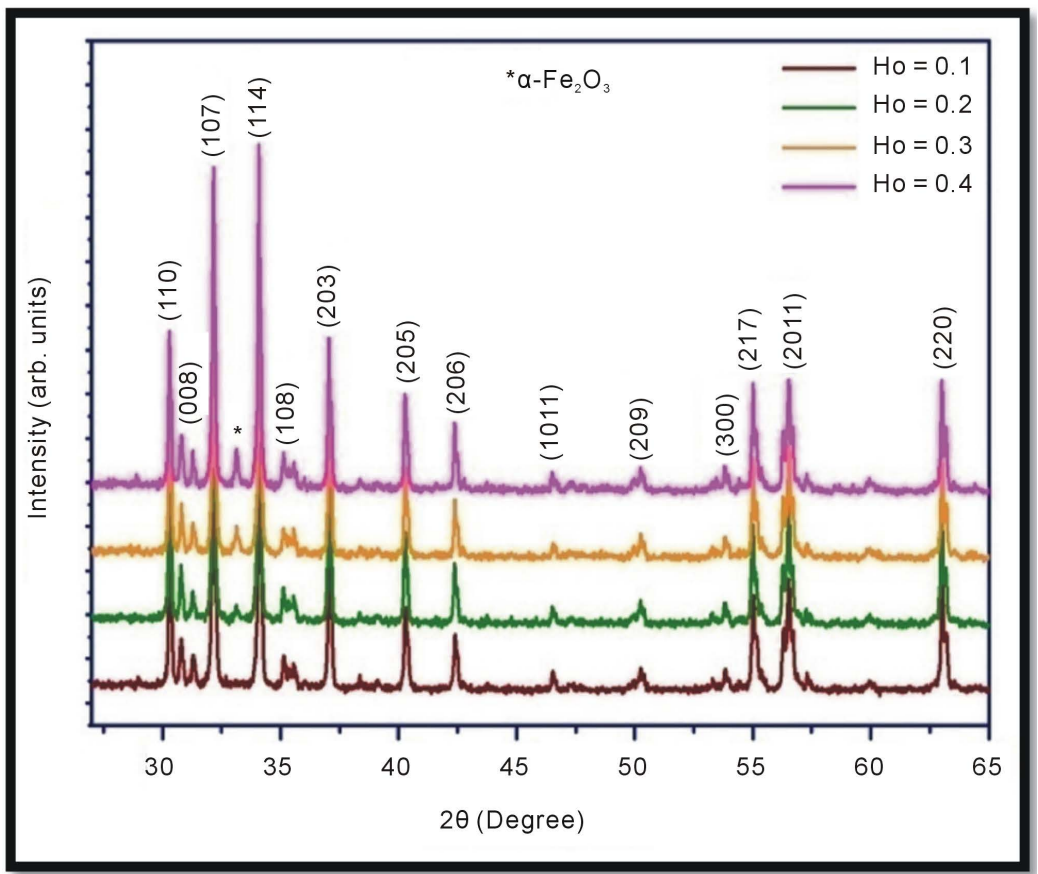

Figure 10. XRD patterns of $\mathrm{BaHo}_{\mathrm{x}} \mathrm{Fe}_{12-\mathrm{x}} \mathrm{O}_{19}$ nanohexaferrites [91].

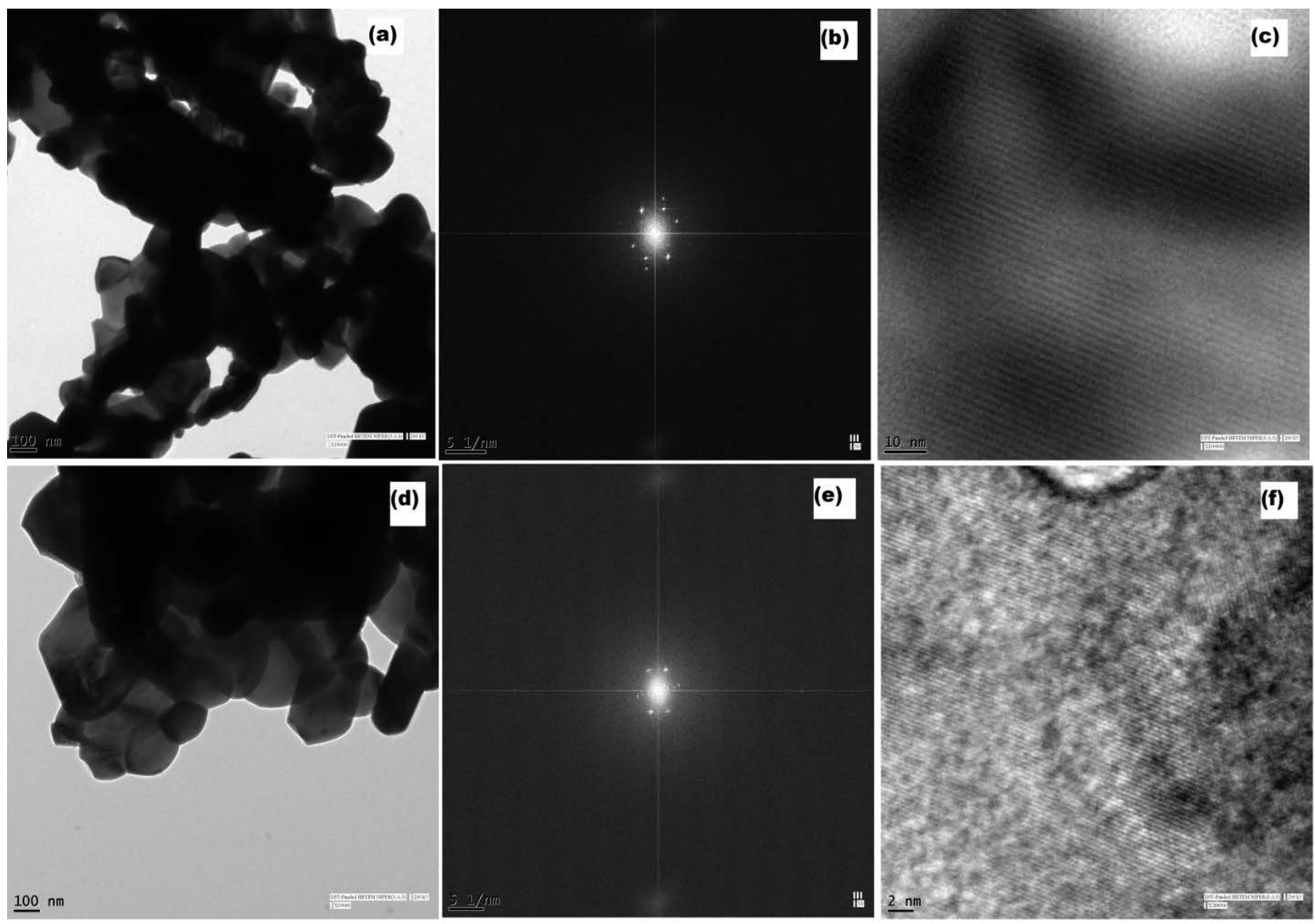

Figure 11. (a)TEM image (b) SAED pattern (c) HRTEM image of $\mathrm{BaHo}_{0.3} \mathrm{Fe}_{11.70} \mathrm{O}_{19}$ nanohexaferrites sample and (d) TEM image (e) SAED pattern (f) HRTEM images of $\mathrm{BaHo}_{0.4} \mathrm{Fe}_{11.60} \mathrm{O}_{19}$ nanohexaferrites sample [91]. 


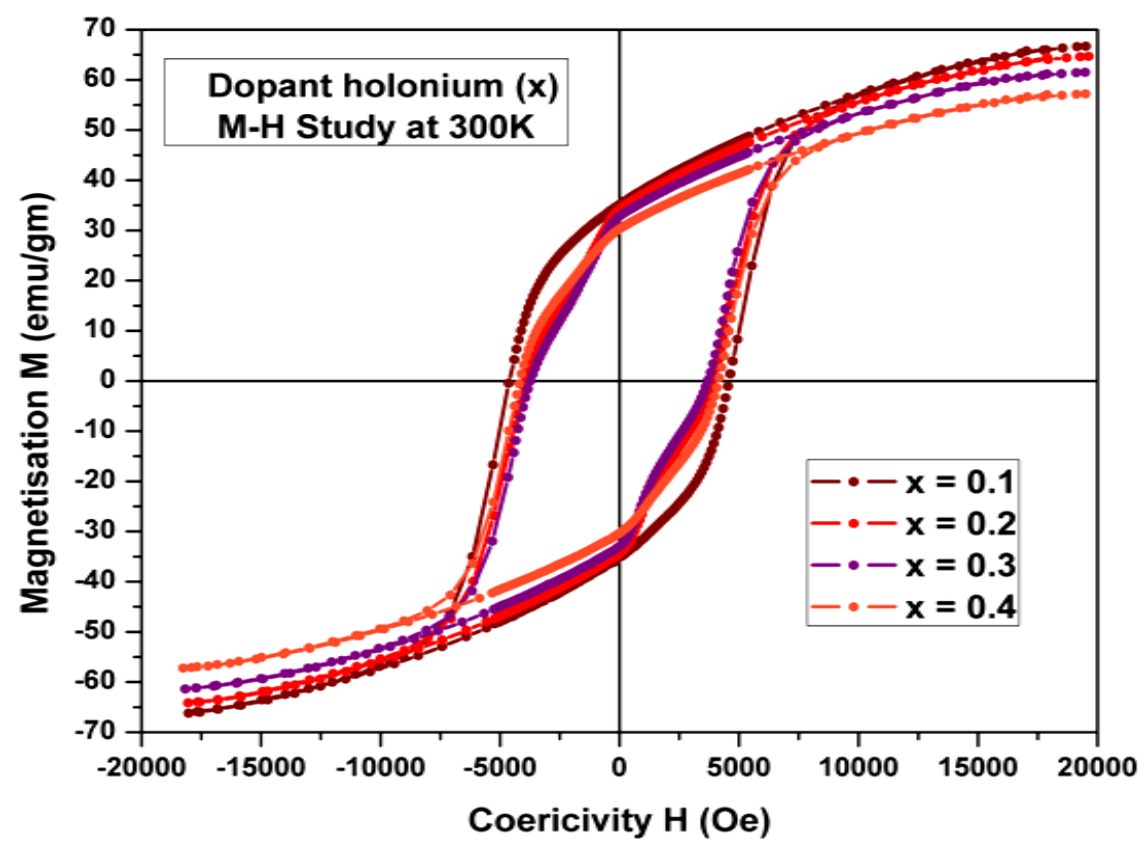

Figure 12. Room temperature variation of magnetization with applied coercive field for $\mathrm{BaHoxFe}_{12-\mathrm{x}} \mathrm{O}_{19}(\mathrm{x}=0.1 .0 .2,0.3,0.4)[91]$.

as a function of applied magnetic field of Holonium substituted BaM nanohexaferrites for $\mathrm{x}=0.1,0.2,0.3,0.4$ shows that the saturation magnetization decreases with the increase in doping of $\mathrm{Ho}^{3+}$ ions.

\section{Conclusion}

In this review paper, we have studied the effect of experimental techniques on the various magnetic properties of $\mathrm{M}$-type hexaferrites. A number of techniques are used for synthesizing the M-type hexaferrites and also, for modifying their magnetic properties, at presently. It is depicted from various studies that chemical wet synthesis techniques are more effective as compared to conventional ceramic techniques. In addition to that, proper selection of dopants has direct effect on the structural and magnetic properties of M-type hexaferrites as shown in case of lanthanides substituted $\mathrm{BaM}$ hexaferrites. Magnetic parameters like saturation magnetization, magnetic retetentivity, coercivity, squareness ratio and magneton numbers may be explored on perfect substituent, intensively used in magnetic storage devices and recording industry. In the nut shell, we conclude that these types of hybrid magnetic materials have wide range of applications in the field of radar technology, wireless communication technology, satellite technology and miniaturization antenna technologies up to ultra high frequency range $(1-50 \mathrm{GHz})$ where low frequency ferrite based magnetic materials have shown their limit.

\section{Acknowledgements}

Corresponding author Virender Pratap Singh is thankful to Indian agency 
DRDO for its constant support and funding through the whole research work (Project No. ERIP/PR/1303129/M/01/1564). One more author K. M. Batoo is thankful to the Deanship of Scientific Research at King Saud University for its funding through the Research Group Project No. RG-1437-030.

\section{References}

[1] Smit, J. and Wijn, H.P.J. (1959) Ferrites. Phil. Techn Lib., Eindhoven, 177.

[2] Kojima, H. and Wohlfarth (1953) Ferromagnetic Materials. Amsterdam, 3, 305. https://doi.org/10.1016/S1574-9304(05)80091-4

[3] Feynman, R.P., Leighton, R.B. and Sands, M. (2005) The Feynman Lectures on Physics. 2nd Edition, Chapter 34, Addison-Wesley, Boston.

[4] Rathenau, G.W., Smit, J. and Stuyts, A.L. (1952) Ferroxdure: A Class of New Permanent Magnetic Materials. Philips Technical Review, 13, 7.

[5] Landau, L.D. and Lifshitz, E.M. (2008) On the Theory of the Dispersion of Magnetic Permeability in Ferromagnetic Bodies. Physikalische Zeitschrift der Sowjetunion, 53, 14-22.

[6] Weiss, M.T. and Anderson, P.W. (1955) Ferromagnetic Resonance in Ferroxdure. Physical Review, 98, 925-926. https://doi.org/10.1103/PhysRev.98.925

[7] Sixtus, K.J., Kronenberg, K.J. and Tenzer, R.K. (1956) Investigations on Barium Ferrite Magnets. Journal of Applied Physics, 27, 1051-1057. https://doi.org/10.1063/1.1722540

[8] Harris, V.G., Chen, Z., Chen, Y., Yoon, S., Sakai, T., Gieler, A., Yang, A., He, Y., Ziemer, K.S., Sun, N.X. and Vittoria, C. (2006) Ba-Hexaferrite Films for Next Generation Microwave Devices (Invited). Journal of Applied Physics, 99, 08 M911.

[9] Ozgur, U., Alivov, Y. and Morkoc, H. (2009) Microwave Ferrites, Part 1: Fundamental Properties. Journal of Materials Science: Materials in Electronics, 20, 789-834. https://doi.org/10.1007/s10854-009-9923-2

[10] Pullar, R.C. (2012) Hexagonal Ferrites: A Review of the Synthesis, Properties and Applications of Hexaferrite Ceramics. Progress in Materials Science, 57, 1191-1334. https://doi.org/10.1016/j.pmatsci.2012.04.001

[11] Braun, P.B. (1957) The Crystal Structure of a New Group of Ferromagnetic Compounds. Philips Research Reports, 12, 491-548.

[12] Sugimoto, M. and Wohfarth, E.P. (1980) Ferromagnetic Materials. North-Holland Physics Publishing, Amsterdam, Vol. 3, 392-440.

[13] Kamishima, K., Hosaka, N., Kakizaki, K. and Hiratsuka, N. (2011) Crystallographic and Magnetic Properties of $\mathrm{Cu}_{2} \mathrm{X}, \mathrm{Co}_{2} \mathrm{X}$ and $\mathrm{Ni}_{2} \mathrm{X}$ Hexaferrites. Journal of Applied Physics, 109, Article ID: 013904. https://doi.org/10.1063/1.3527933

[14] Bertaut, F., Deschamps, A. and Pauthenet, R. (1958) Comptes Rendus de P Académie des Sciences, 246, 2594-9597.

[15] Albanese, G. and Deriu, A. (1979) Magnetic Properties of Al, Ga, Sc, in Substituted Barium Ferrits: A Comparative Analysis. Ceramurgia International, 5, 3-10. https://doi.org/10.1016/0390-5519(79)90002-4

[16] Von Aulok, W.H. (1965) Handbook of Microwave Ferrites. Academic Press, New York.

[17] Adelskold, V. (1938) Crystal Structure of Lead Dodecairon (III) Oxide. Arkiv för Kemi, Mineralogi och Geologi A, 12, 1-9. 
[18] (2012) Structures of $\mathrm{BaFe}_{12} \mathrm{O}_{19}$. http://som.web.cmu.edu/structures/S063-BaFe12O19.html

[19] Kreisel, J., Lucazeau, G. and Vincent, H. (1999) Raman Study of Substituted Barium Ferrite Single Crystals, $\mathrm{BaFe}_{12-2 \mathrm{x}} \mathrm{Me}_{\mathrm{x}} \mathrm{Co}_{\mathrm{x}} \mathrm{O}_{19}(\mathrm{Me}=\mathrm{Ir}, \mathrm{Ti})$. Raman Spectroscopy, 30, 115-120.

https://doi.org/10.1002/(SICI)1097-4555(199902)30:2<115::AID-JRS354>3.0.CO;2D

[20] Kreisel, J., Vincent, H., Tasset, F., Paté, M. and Ganne, J.P. (2001) An Investigation of the Magnetic Anisotropy Change in $\mathrm{BaFe}_{12-2 \mathrm{x}} \mathrm{Ti}_{\mathrm{x}} \mathrm{Co}_{\mathrm{x}} \mathrm{O}_{19}$ Single Crystals. Journal of Magnetism and Magnetic Materials, 224, 17-29. https://doi.org/10.1016/S0304-8853(00)01355-X

[21] Fu, H., Zhai, H.R., Zhang, H.C., Gu, B.X. and Li, J.Y. (1986) Magnetic Properties of Mn Substituted Barium Ferrite. Journal of Magnetism and Magnetic Materials, 54-57, 905-906. https://doi.org/10.1016/0304-8853(86)90307-0

[22] Gershov, I.Y. (1964) Barium Ferrite Permanent Magnets. Soviet Powder Metallurgy and Metal Ceramics, 1, 386-393. https://doi.org/10.1007/BF00774124

[23] Naiden, E.P., Itin, V.I. and Terekhova, O.G. (2003) Mechanochemical Modification of the Phase Diagrams of Hexagonal Oxide Ferrimagnets. Technical Physics Letters, 29, 889-891. https://doi.org/10.1134/1.1631354

[24] Mahmood, S.H., Aloqaily, A.N., Maswadeh, Y., Awadallah, A., Bsoul, I., Awawdeh, M. and Juwhari, H.K. (2015) Effects of Heat Treatment on the Phase Evolution, Structural, and Magnetic Properties of Mo-Zn Doped M-Type Hexaferrites. Solid State Phenomena, 232, 65-92. https://doi.org/10.4028/www.scientific.net/SSP.232.65

[25] Mahmood, S., Aloqaily, A., Maswadeh, Y., Awadallah, A., Bsoul, I. and Juwhari, H. (2014) Structural and Magnetic Properties of Mo-Zn Substituted ( $\left.\mathrm{BaFe}_{12-4 \mathrm{x}} \mathrm{Mo}_{\mathrm{x}} \mathrm{Zn}_{3 \mathrm{x}} \mathrm{O}_{19}\right)$ M-Type Hexaferrites. Material Science Research India, 11, 9-20. https://doi.org/10.13005/msri/110102

[26] Turilli, G., Licci, F., Rinaldi, S. and Deriu, A. (1986) $\mathrm{Mn}^{2+}, \mathrm{Ti}^{4+}$ Substituted Barium Ferrite. Journal of Magnetism and Magnetic Materials, 59, 127-131. https://doi.org/10.1016/0304-8853(86)90019-3

[27] Awadallah, A., Mahmood, S.H., Maswadeh, Y., Bsoul, I., Awawdeh, M., Mohaidat, Q.I. and Juwhari, H. (2016) Structural, Magnetic, and Mossbauer Spectroscopy of $\mathrm{Cu}$ Substituted M-Type Hexaferrites. Materials Research Bulletin, 74, 192-201. https://doi.org/10.1016/j.materresbull.2015.10.034

[28] Ozkan, O.T. and Erkalfa, H. (1994) The Effect of $\mathrm{B}_{2} \mathrm{O}_{3}$ Addition on the Direct Sintering of Barium Hexaferrite. Journal of the European Ceramic Society, 14, 351-358. https://doi.org/10.1016/0955-2219(94)90072-8

[29] Lisjak, D. and Drofenik, M. (2007) The Mechanism of the Low-Temperature Formation of Barium Hexaferrite. Journal of the European Ceramic Society, 27, 4515-4520. https://doi.org/10.1016/j.jeurceramsoc.2007.02.202

[30] Wang, J.P., Ying, L., Zhang, M.L., Qiao, Y.J. and Tian, X. (2008) Comparison of the Sol-Gel Method with the Coprecipitation Technique for Preparation of Hexagonal Barium Ferrite. Chemical Research in Chinese Universities, 24, 525-528. https://doi.org/10.1016/S1005-9040(08)60110-5

[31] Harikrishnan, V., Saravanan, P., Vizhi, R.E., Babu, D.R., Vinod, V., Kejzlar, P. and Černík, M. (2016) Effect of Annealing Temperature on the Structural and Magnetic Properties of CTAB Capped $\mathrm{SrFe}_{12} \mathrm{O}_{19}$ Platelets. Journal of Magnetism and Magnetic Materials, 401,775-783. https://doi.org/10.1016/j.jmmm.2015.10.122

[32] Davoodi, A. and Hashemi, B. (2012) Investigation of the Effective Parameters on 
the Synthesis of Strontium Hexaferrite Nanoparticles by Chemical Coprecipitation Method. Journal of Alloys and Compounds, 512,179-184.

https://doi.org/10.1016/j.jallcom.2011.09.059

[33] Janasi, S.R., Rodrigues, D., Landgraf, F.J. and Emura, M. (2000) Magnetic Properties of Coprecipitated Barium Ferrite Powders as a Function of Synthesis Conditions. IEEE Transactions on Magnetics, 36, 3327-3329. https://doi.org/10.1109/20.908788

[34] Jacobo, S.E., Domingo-Pascual, C., Rodrigez-Clemente, R. and Blesa, M.A. (1997) Synthesis of Ultrafine Particles of Barium Ferrite by Chemical Coprecipitation. Journal of Materials Science, 32, 1025-1028. https://doi.org/10.1023/A:1018582423406

[35] Matutes-Aquino, J., Diaz-Castanón, S., Mirabal-Garcia, M. and Palomares-Sánchez, S. (2000) Synthesis by Coprecipitation and Study of Barium Hexaferrite Powders. Scripta Materialia, 42, 295-299. https://doi.org/10.1016/S1359-6462(99)00350-4

[36] Shepherd, P., Mallick, K.K. and Green, R.J. (2007) Magnetic and Structural Properties of M-Type Barium Hexaferrite Prepared by Co-Precipitation. Journal of Magnetism and Magnetic Materials, 311, 683-692. https://doi.org/10.1016/j.jmmm.2006.08.046

[37] Gulshan, F. and Okada, K. (2013) The Preparation of Alumina-Iron Oxide Compounds by Coprecipitation Method and Its Characterization. American Journal of Materials Science and Engineering, 1, 6-11.

[38] Jamalian, M. (2015) An Investigation of Structural, Magnetic and Microwave Properties of Strontium Hexaferrite Nanoparticles Prepared by a Sol-Gel Process with Doping Sn and Tb. Journal of Magnetism and Magnetic Materials, 378, 217-220. https://doi.org/10.1016/j.jmmm.2014.11.047

[39] Zhong, W., Ding, W., Zhang, N., Hong, J., Yan, Q. and Du, Y. (1997) Key Step in Synthesis of Ultrafine $\mathrm{BaFe}_{12} \mathrm{O}_{19}$ by Sol-Gel Technique. Journal of Magnetism and Magnetic Materials, 168, 196-202. https://doi.org/10.1016/S0304-8853(96)00664-6

[40] Ninad, B., Patil, D., Shelka, A.R., Deshpande, N.G. and Puri, V.R. (2015) Structural, Dielectric and Magnetic Properties of Nickel Substituted Cobalt Ferrite Nanoparticles: Effect of Nickel Concentration. AIP Advances, 5, Article ID: 097166.

[41] Alange, R.C., Khirade, P.P., Birajdar, S.D., Humbe, A.V. and Jadhav, K.M. (2016) Structural, Magnetic and Dielectric Properties of Al-Cr Co-Substituted M-Type Barium Hexaferrite Nanoparticles. Journal of Molecular Structure, 1106, 460-467. https://doi.org/10.1016/j.molstruc.2015.11.004

[42] Mahmood, S.H., Jaradat, F.S., Lehlooh, A.F. and Hammoudeh, A. (2014) Structural Properties and Hyperfine Interactions in Co-Zn Y-Type Hexaferrites Prepared by Sol-Gel Method. Ceramics International, 40, 5231-5236.

https://doi.org/10.1016/j.ceramint.2013.10.092

[43] Abbas, W., Ahmad, I., Kanwal, M., Murtaza, G., Ali, I., Khan, M.A., Akhtar, M.N. and Ahmad, M. (2015) Structural and Magnetic Behavior of Pr-Substituted M-Type Hexagonal Ferrites Synthesized by Sol-Gel Auto-Combustion for a Variety of Applications. Journal of Magnetism and Magnetic Materials, 374, 187-191. https://doi.org/10.1016/j.jmmm.2014.08.029

[44] Thompson, S., Shirtcliffe, N.J., O’Keefe, E.S., Appleton, S. and Perry, C.C. (2005) Synthesis of $\mathrm{SrCo}_{\mathrm{x}} \mathrm{Ti}_{\mathrm{x}} \mathrm{Fe}_{(12-2 \mathrm{x})} \mathrm{O}_{19}$ through Sol-Gel Auto-Ignition and Its Characterisation. Journal of Magnetism and Magnetic Materials, 297, 100-1007. https://doi.org/10.1016/j.jmmm.2004.10.102

[45] Meng, Y., He, M., Zeng, Q., Jiao, D., Shukla, S., Ramanujan, R. and Liu, Z. (2014) Synthesis of Barium Ferrite Ultrafine Powders by a Sol-Gel Combustion Method 
Using Glycine Gels. Journal of Alloys and Compounds, 583, 220-225.

https://doi.org/10.1016/j.jallcom.2013.08.156

[46] Bahadur, D., Rajakumar, S. and Kumar, A. (2006) Influence of Fuel Ratios on Auto Combustion Synthesis of Barium Ferrite Nano Particles. Journal of Chemical Sciences, 118, 15-21. https://doi.org/10.1007/BF02708761

[47] Shi, L., Zeng, C., Jin, T., Wang, T. and Tsabaki, N. (2012) A Sol-Gel Auto-Combustion Method to Prepare $\mathrm{Cu} / \mathrm{ZnO}$ Catalysis for Low Temp. Methanol Synthesis, 2, 2569-2577.

[48] Byrappa, K. and Yoshimura, M. (2001) Handbook of Hydrothermal Technology. Noyes Publications, Park Ridge.

[49] Liu, Wang, J., Gan, L.M. and Ng, S.C. (1999) Improving the Magnetic Properties of Hydrothermally Synthesized Barium Ferrite. Journal of Magnetism and Magnetic Materials, 195, 452-459. https://doi.org/10.1016/S0304-8853(99)00123-7

[50] Ataie, A., Harris, I. and Ponton, C. (1995) Magnetic Properties of Hydrothermally Synthesized Strontium Hexaferrite as a Function of Synthesis Conditions. Journal of Materials Science, 30, 1429-1433. https://doi.org/10.1007/BF00375243

[51] Primc, D., Makovec, D., Lisjak, D. and Drofenik, M. (2009) Hydrothermal Synthesis of Ultrafine Barium Hexaferrite Nanoparticles and the Preparation of Their Stable Suspensions. Nanotechnology, 20, 315-605. https://doi.org/10.1088/0957-4484/20/31/315605

[52] Drofenik, M., Ban, I., Makovec, D., Makovec, A., Jagličić, Z., Hanžel, D. and Lisjak, D. (2011) The Hydrothermal Synthesis of Super-Paramagnetic Barium Hexaferrite Particles. Materials Chemistry and Physics, 127, 415-419. https://doi.org/10.1016/j.matchemphys.2011.02.037

[53] Joshi, N., Grewal, G.S., Shrinet, V., Pratap, A. and Buch, N.J. (2010) Synthesis and Characterization of Nano-Barium Titanate Prepared by Hydrothermal Process. Integrated Ferroelectrics, 115, 142-148. https://doi.org/10.1080/10584587.2010.496614

[54] Ahmed, T.T., Rahmanand, I.Z. and Rahman, M.A. (2004) Study on the Properties of the Copper Substituted NiZn Ferrites. Proceedings of the International Conference in Advances in Materials and Processing Technologies, 153-154, 797-803. https://doi.org/10.1016/j.jmatprotec.2004.04.188

[55] Nakamura Rao, T., Okanoand, Y. and Miura, S. (1998) Interfacial Diffusion between Ni-Zn-Cu Ferrite and Ag during Sintering. Journal of Materials Science, 33, 1091-1094. https://doi.org/10.1023/A:1004344719076

[56] Sankaranarayanan, V., Pankhurst, Q., Dickson, D. and Johnson, C. (1993) Ultrafine Particles of Barium Ferrite from a Citrate Precursor. Journal of Magnetism and Magnetic Materials, 120, 73-75. https://doi.org/10.1016/0304-8853(93)91290-N

[57] Sankaranarayanan, V. and Khan, D. (1996) Mechanism of the Formation of Nanoscale M-Type Barium Hexaferrite in the Citrate Precursor Method. Journal of Magnetism and Magnetic Materials, 153, 337-346. https://doi.org/10.1016/0304-8853(95)00537-4

[58] Sankaranarayanan, V., Pankhurst, Q., Dickson, D. and Johnson, C. (1993) An Investigation of Particle Size Effects in Ultrafine Barium Ferrite. Journal of Magnetism and Magnetic Materials, 125, 199-208. https://doi.org/10.1016/0304-8853(93)90838-S

[59] Shankar, V., Ahmad, T. and Ganguli, A.K. (2004) Investigation of $\mathrm{Ba}_{2-\mathrm{x}} \mathrm{Sr}_{\mathrm{x}} \mathrm{TiO}_{4}$ : Structural Aspects and Dielectric Properties. Bulletin of Materials Science, 27, 421-427. https://doi.org/10.1007/BF02708558 
[60] Arendt, R.H. (1973) The Molten Salt Synthesis of Single Domain $\mathrm{BaFe}_{12} \mathrm{O}_{19}$ and $\mathrm{SrFe}_{12} \mathrm{O}_{19}$ Crystals. Journal of Solid State Chemistry, 8, 339-347. https://doi.org/10.1016/S0022-4596(73)80031-3

[61] Chin, T.S., Hsu, S. and Deng, M. (1993) Barium Ferrite Particulates Prepared by a Salt-Melt Method. Journal of Magnetism and Magnetic Materials, 120, 64-68. https://doi.org/10.1016/0304-8853(93)91288-I

[62] Kimura, T. (2011) Molten Salt Synthesis of Ceramic Powders. In: Advances in Ceramics, IntechOpen, London, 75-100. https://doi.org/10.5772/20472

[63] Topal, U. (2012) Improvement of the Remanence Properties and the Weakening of Interparticle Interactions in $\mathrm{BaFe}_{12} \mathrm{O}_{19}$ Particles by $\mathrm{B}_{2} \mathrm{O}_{3}$ Addition. Physica B: Condensed Matter, 407, 2058-2062. https://doi.org/10.1016/j.physb.2012.02.004

[64] Topal, U. (2012) Towards Further Improvements of the Magnetization Parameters of $\mathrm{B}_{2} \mathrm{O}_{3}$-Doped $\mathrm{BaFe}_{12} \mathrm{O}_{19}$ Particles: Etching with Hydrochloric Acid. Journal of Superconductivity and Novel Magnetism, 25, 1485-1488. https://doi.org/10.1007/s10948-012-1486-4

[65] Mohsen, Q. (2010) Barium Hexaferrite Synthesis by Oxalate Precursor Route. Journal of Alloys and Compounds, 500, 125-128. https://doi.org/10.1016/j.jallcom.2010.03.230

[66] Topal, U., Ozkan, H. and Dorosinskii, L. (2007) Finding Optimal Fe/Ba Ratio to Obtain Single Phase $\mathrm{BaFe}_{12} \mathrm{O}_{19}$ Prepared by Ammonium Nitrate Melt Technique. Journal of Alloys and Compounds, 428, 17-21. https://doi.org/10.1016/j.jallcom.2006.03.047

[67] Topal, U., Ozkan, H. and Sozeri, H. (2004) Synthesis and Characterization of Nanocrystalline $\mathrm{BaFe}_{12} \mathrm{O}_{19}$ Obtained at $850{ }^{\circ} \mathrm{C}$ by Using Ammonium Nitrate Melt. Journal of Magnetism and Magnetic Materials, 284, 416-422. https://doi.org/10.1016/j.jmmm.2004.07.009

[68] El-Sayed, S., Meaz, T., Amer, M. and El Shersaby, H. (2013) Magnetic Behavior and Dielectric Properties of Aluminum Substituted M-Type Barium Hexaferrite. Physica B: Condensed Matter, 426, 137-143. https://doi.org/10.1016/j.physb.2013.06.026

[69] Soman, V.V., Nanoti, V. and Kulkarni, D. (2013) Dielectric and Magnetic Properties of Mg-Ti Substituted Barium Hexaferrite. Ceramics International, 39, 5713-5723. https://doi.org/10.1016/j.ceramint.2012.12.089

[70] Bsoul, I. and Mahmood, S. (2010) Magnetic and Structural Properties of $\mathrm{BaFe}_{12-\mathrm{x}} \mathrm{Ga}_{\mathrm{x}} \mathrm{O}_{19}$ Nanoparticles. Journal of Alloys and Compounds, 489, 110-114. https://doi.org/10.1016/j.jallcom.2009.09.024

[71] Yu, H.F. (2013) $\mathrm{BaFe}_{12} \mathrm{O}_{19}$ Powder with High Magnetization Prepared by Acetone-Aided Coprecipitation. Journal of Magnetism and Magnetic Materials, 341, 79-85. https://doi.org/10.1016/j.jmmm.2013.04.030

[72] Pashkova, E., Solovyova, E., Kotenko, I., Kolodiazhnyi, T. and Belous, A. (2011) Effect of Preparation Conditions on Fractal Structure and Phase Transformations in the Synthesis of Nanoscale M Type Barium Hexaferrite. Journal of Magnetism and Magnetic Materials, 323, 2497-2503. https://doi.org/10.1016/j.jmmm.2011.05.026

[73] Kaur, T. and Srivastava, A. (2013) Effect of pH on Magnetic Properties of Doped Barium Hexaferrite. International Journal of Research in Mechanical Engineering \& Technology, 3, 171-173.

[74] Khademi, F., Poorbafrani, A., Kameli, P. and Salamati, H. (2012) Structural, Magnetic and Microwave Properties of Eu-Doped Barium Hexaferrite Powders. Journal of Superconductivity and Novel Magnetism, 25, 525-531. 
https://doi.org/10.1007/s10948-011-1323-1

[75] Li, Y., Wang, Q.Z. and Yang, H. (2009) Synthesis, Characterization and Magnetic Properties on Nanocrystalline $\mathrm{BaFe}_{12} \mathrm{O}_{19}$ Ferrite. Current Applied Physics, 9, 1375-1380. https://doi.org/10.1016/j.cap.2009.03.002

[76] Dursun, S., Topkaya, R., Akdoğan, N. and Alkoy, S. (2012) Comparison of the Structural and Magnetic Properties of Submicron Barium Hexaferrite Powders Prepared by Molten Salt and Solid State Calcination Routes. Ceramics International, 38, 3801-3806. https://doi.org/10.1016/j.ceramint.2012.01.028

[77] Liu, Y., Drew, M.G., Liu, Y., Wang, J. and Zhang, M. (2010) Preparation, Characterization and Magnetic Properties of the Doped Barium Hexaferrites $\mathrm{BaFe}_{12-2 \mathrm{x}} \mathrm{Co}_{\mathrm{x} / 2} \mathrm{Zn}_{\mathrm{x} / 2} \mathrm{Sn}_{\mathrm{x}} \mathrm{O}_{19}, \mathrm{x}=0.0$ 2.0. Journal of Magnetism and Magnetic Materials, 322, 814-818. https://doi.org/10.1016/j.jmmm.2009.11.009

[78] Yamauchi, T., Tsukahara, Y., Sakata, T., Mori, H., Chikata, T., Katoh, S. and Wada, Y. (2009) Barium Ferrite Powders Prepared by Microwave-Induced Hydrothermal Reaction and Magnetic Property. Journal of Magnetism and Magnetic Materials, 321, 8-11. https://doi.org/10.1016/j.jmmm.2008.07.005

[79] Kitakami, O., Goto, K. and Sakurai, T. (1988) A Study of the Magnetic Domains of Isolated Fine Particles of Ba Ferrite. Japanese Journal of Applied Physics, 27, 2274-2277. https://doi.org/10.1143/JJAP.27.2274

[80] Hirayama, T., Ru, Q., Tanki, T. and Tonomura, A. (1993) Observation of Magnetic-Domain States of Barium Ferrite Particles by Electron Holography. Applied Physics Letters, 63, 418. https://doi.org/10.1063/1.110011

[81] Went, J.J., Rathenau, G.W., Gorter, E.W. and Van Oosterhout, G.W. (1952) Hexagonal Iron-Oxide Compounds as Permanent-Magnet Materials. Physical Review Journals Archive, 86, 424. https://doi.org/10.1103/PhysRev.86.424.2

[82] Brahma, P., Giri, A.K., Chakravorty, D., Roy, M. and Bahadur, D. (1992) Magnetic Properties of $\mathrm{As}_{2} \mathrm{O}_{3}$ - and $\mathrm{Sb}_{2} \mathrm{O}_{3}$-Doped Ba-M Hexagonal Ferrites Prepared by the Sol-Gel Method. Journal of Magnetism and Magnetic Materials, 117, 163-168. https://doi.org/10.1016/0304-8853(92)90306-9

[83] Li, C.J., Wang, B. and Wang, J.-N. (2012) Magnetic and Microwave Absorbing Properties of Electrospun $\mathrm{Ba}_{(1-\mathrm{x})} \mathrm{La}_{\mathrm{x}} \mathrm{Fe}_{12} \mathrm{O}_{19}$ Nanofibers. Journal of Magnetism and Magnetic Materials, 324, 1305-1311. https://doi.org/10.1016/j.jmmm.2011.11.016

[84] Dhage, V.N., Mane, M.L., Babrekar, M.K., Kale, C.M. and Jadhav, K.M. (2011) Influence of Chromium Substitution on Structural and Magnetic Properties of $\mathrm{BaFe}_{12} \mathrm{O}_{19}$ Powder Prepared by Sol-Gel Auto Combustion Method. Journal of Alloys and Compounds, 509, 4394-4398. https://doi.org/10.1016/j.jallcom.2011.01.040

[85] Lee, J., Hong, Y.-K., Lee, W., Abo, G.S., Park, J., Neveu, N., Seong, W.-M., Park, S.-H. and Ahn, W.-K. (2012) Soft M-Type Hexaferrite for Very High Frequency Miniature Antenna Applications. Journal of Applied Physics, 111, 07A520. https://doi.org/10.1063/1.3679468

[86] Rai, G.M., Iqbal, M.A. and Kubra, K.T. (2010) Effect of $\mathrm{Ho}^{3+}$ Substitutions on the Structural and Magnetic Properties of $\mathrm{BaFe}_{12} \mathrm{O}_{19}$ Hexaferrites. Journal of Alloys and Compounds, 495, 229-233. https://doi.org/10.1016/j.jallcom.2010.01.133

[87] Litsardakis, G., Manolakis, J. and Efthimiadis, K. (2007) Structural and Magnetic Properties of Barium Hexaferrites with Gd-Co Substitution. Journal of Alloys and Compounds, 427, 194-198. https://doi.org/10.1016/j.jallcom.2006.02.044

[88] Litsardakis, G., Manolakis, J., Serletis, C. and Efthimiadis, K.G. (2007) Structural and Magnetic Properties of Barium-Gadolinium Hexaferrites. Journal of Magnetism and Magnetic Materials, 310, e884-e886. 
https://doi.org/10.1016/j.jmmm.2006.10.1107

[89] Iqbal, M.J. and Farooq, S. (2010) Impact of Pr-Ni Substitution on the Electrical and Magnetic Properties of Chemically Derived Nanosized Strontium-Barium Hexaferrites. Journal of Alloys and Compounds, 505, 560-567.

https://doi.org/10.1016/j.jallcom.2010.06.073

[90] Verwey, E.J.W. and Boer, J.H. (1936) Cation Arrangement in a Few Oxides with Crystal Structures of the Spinel Type. Recueil des Travaux Chimiques des Pays-Bas, 55, 531- 540. https://doi.org/10.1002/recl.19360550608

[91] Singh, V.P. (2015) Study of Substituted M-Type Barium Nanohexaferrites Synthesized via Sol-Gel Auto Combustion Technique. PhD Dissertation, Himachal Pradesh University, Shimla. 